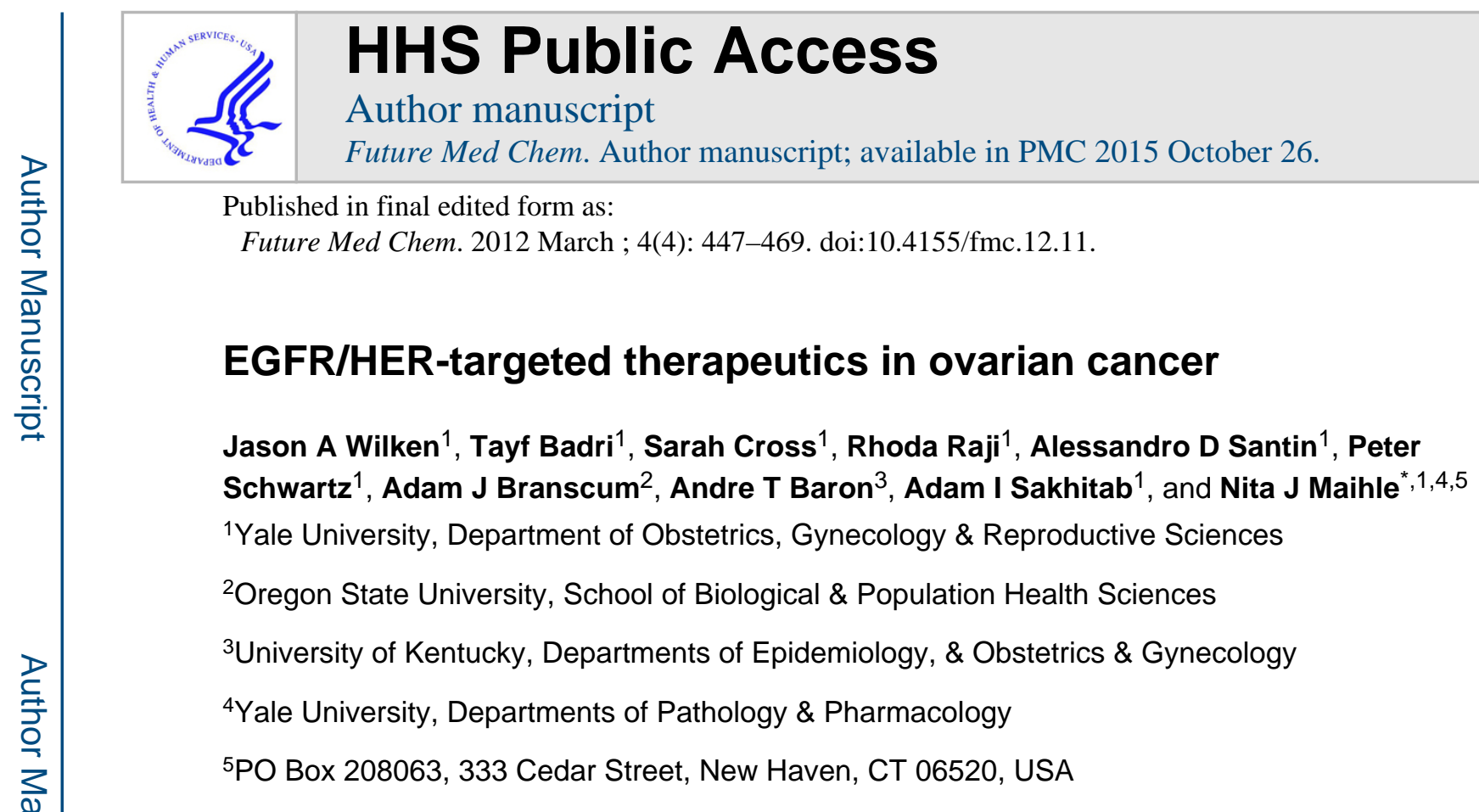

\title{
Abstract
}

\begin{abstract}
Despite decades of research and evolving treatment modalities, survival among patients with epithelial ovarian cancer has improved only incrementally. During this same period, the development of biologically targeted therapeutics has improved survival for patients with diverse malignancies. Many of these new drugs target the human epidermal growth factor receptor (EGFR/HER/ErbB) family of tyrosine kinases, which play a major role in the etiology and progression of many carcinomas, including epithelial ovarian cancer. While several HER-targeted therapeutics are US FDA approved for the treatment of various malignancies, none have gained approval for the treatment of ovarian cancer. Here, we review the published literature on HERtargeted therapeutics for the treatment of ovarian cancer, including novel HER-targeted therapeutics in various stages of clinical development, as well as the challenges that have limited the use of these inhibitors in clinical settings.
\end{abstract}

\begin{abstract}
Ovarian cancer is the most lethal gynecological malignancy in the USA. It is estimated that in the USA in 2012, 22,280 women will be diagnosed with epithelial ovarian cancer (EOC), and 15,500 women will die of the disease in 2012; by comparison, it is estimated that 47,130 women will be diagnosed with endometrial cancer in 2012, and 8010 women will die of the disease [1]. The high mortality rate associated with EOC is attributed to the intrinsically aggressive nature of the disease process and our limited ability to detect earlystage disease. In contrast to breast or cervical cancer, current imaging and available markers are inadequate for diagnosis and preclude population-based screening; unlike uterine cancer, the most common symptoms associated with EOC (e.g., bloating, abdominal pain and early
\end{abstract}

\footnotetext{
*Author for correspondence: Tel.: +1 203623 5142, Fax: +1 203737 2914, nita.maihle @yale.edu.

For reprint orders, please contact reprints@ future-science.com

Supplementary data

To view the supplementary data that accompany this paper please visit the journal website at: http://www.future-science.com/doi/ supp1/10.4155/fmc.12.11

The authors have no other relevant affiliations or financial involvement with any organization or entity with a financial interest in or financial conflict with the subject matter or materials discussed in the manuscript apart from those disclosed.
} 
satiety) are classically nonspecific and may portend advanced disease at the time of clinical presentation, precluding early evaluation based on common symptoms. This translates into a clinical reality that $>70 \%$ of patients have the advanced-stage disease (e.g., spread beyond the pelvis, i.e., stage III or IV) at the time of initial diagnosis. The 5-year survival rate for patients with advanced EOC is only approximately $30 \%$, while that of patients diagnosed with early disease (e.g., localized to the ovary or pelvis, stage I or II) may exceed $90 \%$.

Significant advances have been made in EOC treatment over the past three decades, including the establishment of cytoreductive surgery and combination platinum- and taxanebased chemotherapy as standard of care for first-line management of advanced disease. However, debate continues in regards to the timing and extent of surgical resection compared with the timing and duration of chemotherapy in patients with advanced tumors (primary cytoreductive surgery vs three to six cycles of initial [i.e., 'neoadjuvant'] chemotherapy with interval debulking surgery), and there is no accepted regimen for management of recurrent, relapsed or refractory disease. The role of intraperitoneal chemotherapy continues to evolve and the utility of interval debulking surgery is still under discussion. We may be approaching the limits of our ability to optimize treatment of EOC using conventional chemotherapeutics. Improvements in EOC morbidity and mortality will likely occur with improvements in the early detection of this disease [2], as well as through the application of biologically targeted therapeutics.

While it was initially predicted that therapeutics targeting the HER/ErbB family of receptors would be effective for the treatment of EOC patients based on in vitro studies demonstrating a critical role for HER family members in ovarian cancer cell growth, as well as on the frequent expression of HER family members in ovarian tumors, these new drugs have not achieved target levels of efficacy in early stage clinical trials. While recent reviews have summarized recent studies on the use of biologically targeted inhibitors for the treatment of EOC, including EGFR inhibitors [3-5], the purpose of this report is to present a comprehensive overview of the potential of HER/ErbB-targeted therapeutics for the treatment of EOC, the challenges that have been encountered, and opportunities for overcoming these challenges. In this review, we discuss the current state of EOC treatment, focusing on chemotherapeutic intervention; the current repertoire of HER-targeted therapeutics; and the therapeutic potential of these drugs in EOC patients. Finally, we address the limitations of these early trials and present recommendations for future studies, including new strategies for the design of clinical trials to test this new family of

biologically targeted cancer therapeutics for the treatment of EOC.

\section{Overview of epithelial ovarian cancer treatment}

Many women have asymptomatic pelvic masses that are detected during routine clinical care. While the majority of these masses will be benign, the limitations of available imaging and diagnostic techniques necessitate surgical resection for pathology confirmation of clinically suspected malignancy. For some patients diagnosed with early-stage EOC, optimal surgical debulking alone may be curative. However, a significant body of evidence suggests that even in patients with early-stage disease, histopathology suggestive of a high probability of recurrence (e.g., poor differentiation) and/or disease extending beyond the confinement of 
the ovarian capsule (i.e., stage $1 \mathrm{C}$ or greater) should prompt consideration of adjuvant chemotherapy [6].

Unfortunately, most patients with EOC present with advanced (stage III or IV) disease, and the remainder of this review is focused on the treatment of these women. The standard management in patients with advanced EOC is cytoreductive surgery followed by cytotoxic chemotherapy to eradicate residual or micrometastatic disease. Multiple studies suggest that minimizing tumor burden confers better patient outcome than suboptimal tumor resection, regardless of subsequent chemotherapeutic treatment. The Gynecologic Oncology Group (GOG) defines optimal debulking as having $1 \mathrm{~cm}$ or less of identifiable, macroscopic disease at any site at the completion of surgical resection [7]. The standard initial cytotoxic regimen for management of advanced EOC is a platinum and taxane combination, with intraperitoneal administration gaining increased consideration in patients who are optimally debulked. A myriad of treatment regimens are employed in the management of patients who have significant residual disease after initial surgery and/or have recurrent disease.

Optimal management of recurrent EOC remains elusive. The role of interval cytoreductive surgery is currently under investigation through the GOG and the potential role of radiation therapy in patients with recurrent EOC is unclear. Systemic therapy is, therefore, the mainstay of treatment for these patients, and is largely dependent on the time to disease recurrence following initial platinum-based treatment. Treatment during this phase of the disease is typically administration of successive rounds of various chemotherapeutic agents, with increasing palliative intent, until a point at which unacceptable toxicity/impaired quality of life is reached or no further tumor response is elicited.

Patients with advanced disease have a response rate of 73-77\% to first-line therapy with platinum and taxol, which is standard of care in this population. Even among responders, the median progression-free interval is $16-18$ months and median survival is $35-38$ months $[6,8]$. Further systemic treatment options for patients are selected based on tumor response to platinum. In addition to established chemotherapeutics, a new generation of biologically targeted therapeutics is being explored for the treatment of EOC. This review focuses on a new category of therapeutics that targets the EGFR/HER receptor family signaling axis.

\section{HER family \& ovarian cancer}

The HER family of type I transmembrane receptor tyrosine kinases consists of four structurally related members: EGFR/ErbB1/HER-1, ErbB2/HER-2/neu, ErbB3/HER-3 and ErbB4/HER-4 [9]. HER proteins are structurally subdivided into an extracellular domain (ECD), a transmembrane domain and a cytoplasmic or intracellular domain containing an ATP-binding tyrosine kinase domain and a carboxy-terminal domain (Figure 1). The unliganded ECD exists in an 'open' conformation, capable of binding ligands specific for each HER family member [10]. Following ligand binding, the ECD adopts a 'closed', hetero- or homodimerization conformation. HER receptor dimerization induces transphosphorylation of carboxy-terminal sequences, which function as docking sites for a variety of adaptor proteins and substrates, including STAT-3, STAT-5, PI3K, Ras-GAP, phospholipases $\mathrm{C} \gamma$, Grb2, Grb7, Grb10, Nck, Crk, Cbl, Abl, Shp1, Shp2, Eps8 and Eps15

Future Med Chem. Author manuscript; available in PMC 2015 October 26. 
[11-15]. HER family members can activate an overlapping but distinct repertoire of signaling pathways, resulting in both cell type- and tissue-specific signal transduction [16].

The prototypic ligand-dependent HER activation pathway applies to EGFR and HER4. Although recent reports suggest that membrane MUC4 can act as a ligand for HER2 [1719], HER2 has no known soluble ligand, and is maintained in the closed, receptor-competent state. HER2, therefore, functions as a HER co-receptor and is the preferred heterodimerization partner of EGFR, HER3 and HER4 [20]. Conversely, HER3 has no intrinsic tyrosine kinase activity and, as a result, can only activate ligand-mediated signaling in the context of a HER heterodimer.

HER ligands are synthesized as transmembrane precursors that are proteolytically shed from the cell surface and can be classified by their HER binding patterns. EGF, TGF-a and amphiregulin bind specifically to EGFR. Betacellulin, heparin-binding EGF and epiregulin bind to both EGFR and HER4. Heregulin/neuregulin (HRG/NRG)-1 and HRG-2 bind both HER3 and HER4, while HRG-3 and HRG-4 bind only to HER4.

In addition to full-length transmembrane HER family members, each HER receptor has also been described as a soluble isoform, lacking the TMD and ICD. Soluble isoforms arise from either proteolytic processing of full-length HER holoreceptor or via alternate transcription events [21]. Alternate transcripts of the EGFR, HER2, and HER3 genes incorporating alternate exons (i.e., splice variants) or intron sequences give rise to 'soluble' EGFR, HER2 and HER3 isoforms (sEGFR, sHER2 and sHER3, respectively). Proteolytic processing of HER 2 and HER 4 can also give rise to both soluble and truncated membrane-bound HER receptor isoforms [21]. Soluble HER isoforms impart another level of complexity to the regulation of HER signaling, and sEGFR/sHER expression has been shown to influence tyrosine kinase activity, cell cohesion/compaction, cell survival, proliferation, differentiation and migration [21-23].

In addition, two ECD-truncated membrane-associated HER isoforms (tHER) [21] have a role in the etiology of human malignancies. First, EGFRvIII, a constitutively kinase-active EGFR variant lacking 268 amino acids of the ECD, is frequently expressed in numerous cancers [24]. However, the role of EGFRvIII expression in EOC is controversial. While an early study reported that approximately $73 \%$ of ovarian cancers express EGFRvIII [25], subsequent studies have failed to detect EGFRvIII expression in malignant ovarian tumors [26-28]. Second, p95 tHER2 is a HER2 isoform lacking almost all of the ECD and, freed from ECD-mediated autoinhibition, is a constitutively active kinase; its expression is associated with poor prognosis and resistance to trastuzumab (Herceptin®; a monoclonal antibody that binds to an extracellular domain of HER2) in breast cancer patients $[29,30]$. Two distinct mechanisms that give rise to p95 tHER2 have been identified. Full-length HER2 can be proteolytically cleaved by a metalloprotease, releasing most of the ECD [3133]. Other more recent studies have identified an alternate $H E R 2$ transcript that incorporates an alternate transcription start codon and encodes a p95 tHER2 isoform lacking most of the ECD [34]. While the contribution of p95 tHER2 to the etiology of EOC is unclear, expression of p95 tHER2 has been identified in diverse EOC-derived cell lines [35,36]. 


\section{HER family in normal ovaries}

The HER family of receptors and their ligands control numerous cellular processes including growth, differentiation, adhesion, migration, and survival. As recently reviewed by our group [21], HER family members and their ligands display complex expression patterns in the normal human ovary. 'HER expression' as assessed by immunohistochemistry (IHC) is highly dependent on the choice of primary antibody, as studies using different HERdirected antibodies have yielded disparate results. Moreover, previous studies have not used methods that would allow isoform-specific HER expression patterns to be determined. Most studies have shown that EGFR and HER2 are expressed at moderate levels in the epithelium of the ovary, but at only low or undetectable levels in the ovarian stromal compartment. In the few studies that have examined localization of HER3 and HER4 in human ovary, HER3 was not detected in either the epithelium or stroma, and HER4 was expressed at only low levels in the epithelium and was not detected in stromal tissue.

While the role of the HER family in the biology and etiology of EOC has been extensively studied (see below), relatively little is known about the function of HER family members in normal ovaries. In one notable IHC study, EGFR expression increased during follicular maturation; high EGFR expression was initially noted in primary oocytes, followed by theca interna and granulosa cells, and finally in the corpora lutea during mid-luteal phase, after which time EGFR expression became undetectable [37]. In contrast, another study demonstrated strong HER3 expression in developing follicles and surrounding granulosa cells, but only weak HER3 expression in lutenized granulosa [38]. The observation that HER expression varies throughout the ovulatory cycle suggests an association between HER expression and steroid/gonadotropin hormone levels in the ovary. Indeed, an association between steroid/gonadotropin levels and ovarian HER receptor and/or ligand expression has been demonstrated in vitro and in animal models [21], and circulating HER receptor isoforms have also been correlated with steroid/gonadotropin hormone levels [39,40]. The mechanistic basis for these relationships has not yet been determined.

\section{HER family in epithelial ovarian cancer}

We have recently reviewed the expression of HER family members and their ligands in malignant ovarian tissue and derived cell lines [21], and salient results are briefly summarized here. EGFR expression ranges from 4-100\% in malignant ovarian tissue as demonstrated by IHC, with an average expression frequency of approximately $48 \%$. The utility of EGFR expression as an independent prognostic indicator in EOC patients is controversial, with multiple reports suggesting both that EGFR is $[26,41-46]$ and is not [4755] a reliable marker of survival or responsiveness to therapy.

HER2 is expressed in approximately $40 \%$ of EOC tumors as evaluated by IHC [21], and has been identified as a negative prognostic indicator in EOC [56]. Since this observation, multiple studies have reported contradictory results, regarding the utility of HER2 expression as an indicator of responsiveness to therapy and survival in EOC patients $[49,51,53,57-83]$. 
In one study, HER 3 and HER 4 expression was detected by IHC in approximately 48 and $71 \%$ of EOC tumors, respectively [20]; the expression of these two receptors in EOC has been examined in far fewer studies than EGFR and HER2. HER3 expression has been independently associated with overall survival in EOC [44,84,85], while HER4 expression has not been correlated with survival [86].

Despite the role of the HER family and its cognate ligands in the development and progression of EOC, there is significant controversy regarding the role of HER family members as prognostic indicators in EOC patients. The reasons underlying these discrepancies include a multitude of potential technical and methodological issues, including choice of antibody, the use of frozen versus paraffin-embedded sections, antigen retrieval methods, sample size, degree of observational concordance between pathologists in scoring labeled tumor cells and the potential confounding effects of disease stage, tumor grade and histology, patient age, race and treatment regimen, among others. Another potential confounding factor may be the co-expression of multiple immunoreactive isoforms of HER family members that are indistinguishable by IHC, including soluble and truncated HER isoforms (sHERs/tHERs). The prospective roles of these alternate HER isoforms in the pathophysiology of EOC, as well as their potential utility as diagnostic markers in EOC, have previously been reviewed $[21,87,88]$.

\section{HER-targeted therapeutics}

Given the central role of HER oncogenic signaling in the development and progression of a number of human cancers, substantial resources have been focused on the development of HER-targeted inhibitors for cancer treatment. HER-targeted therapeutics can be divided into two main categories (Figure 1): small-molecule tyrosine kinase inhibitors (TKIs) and therapeutic antibodies (see Table 1 for a list of HER inhibitors reviewed). Other drugs that indirectly target HER pathways, such as geldanamycin (an inhibitor of the HER2-stabilizing chaperone HSP90), have recently been reviewed by others [89].

The 4-anilinoquinazolines and their derivatives comprise the largest class of HER-targeted low-molecular weight TKIs. The first such reported compound was PD153035, a 4-(3bromoanilino)-6,7-dimethoxyquinazoline, which selectively inhibits EGFR via reversible, competitive binding to the ATP-binding domain of EGFR's tyrosine kinase domain [90]. Numerous anilinoquinazolines (including analogs with alkylated side chains for irreversible binding to the ATP pocket), as well as pyrimidines, triazines and triazols, are in various stages of development in clinical trials for the treatment of human malignancies.

HER-directed therapeutic antibodies can be divided into overlapping categories. The first class of antibodies inhibits HER ligand binding, and includes cetuximab and panitumumab (Figure 1). The second class includes antibodies that inhibit HER dimerization, such as matuzumab [91] and pertuzumab [92]. HER-targeted antibodies also may function by recruiting immune cells to induce antibody-dependent cell toxicity (e.g., trastuzumab [9395], 2B1 [96,97] and cetuximab [98,99]) or by inducing HER internalization/degradation (e.g., trastuzumab [100-102] and cetuximab [103]).

Future Med Chem. Author manuscript; available in PMC 2015 October 26. 


\section{Effect of HER inhibitors on epithelial ovarian cancer-derived cells in vitro}

More than 100 reports have detailed the effects of HER inhibitors on a range of ovarian carcinoma-derived cell lines. In Supplementary Table 1, we summarize these studies and distinguish between a drug's ability to inhibit ligand-dependent versus ligand-independent cell growth. It is worth noting that growth inhibition in the absence of ligand may either reflect inhibition of endogenously produced growth factor signaling or may also highlight ligand-independent HER-mediated survival signaling in association with extracellular matrix components [104].

While the majority of reports on a given HER inhibitor in a particular cell line are consonant, a number of discepencies also exist in the literature in terms of inhibitor efficacy and inhibition phenotype (Supplementary Table 1). Possible explanations for these discepencies include differences in assay method, assay duration, drug batch/formulation and handling of HER inhibitor, as well as statistical methods used for data analysis. Other factors include cell line history and culture conditions; passage number of LNCaP prostate cells, for example, is inversely correlated with response to the anti-androgen bicalutamide [105], and trastuzumab growth inhibition of OVCAR-3 cells is dependent on concentration of culture serum [106].

HER-targeted therapeutics have been shown to interact with other compounds to influence EOC cell growth in an additive or synergistic manner (Supplementary Table 1). In addition to growth inhibition, EGFR inhibitors have been shown to alter migration and/or gene expression patterns in EOC cell lines. For example, PD153035 [107-110] inhibits the migration of $\mathrm{CaOV} 3$ cells, and gefitinib inhibits the migration of OVCAR3 and cisplatinresistant A2780 cells [111,112]. Gefitinib inhibits the production of TGF-a, bFGF and VEGF in OVCAR-3 cell lines [113], while PKI-166 inhibits expression of the antiapoptotic protein c-FLIP ${ }_{\mathrm{L}}$ in HEYA8 cells, as well as in SKOV-3 cells [114]. Trastuzumab can alter the phosphorylation pattern of a number of noncanonical proteins of the HER2 signaling axis in certain EOC-derived cell lines [115-117]. To date, however, the mechanistic basis for these myriad effects has not been fully characterized for the inhibitors described.

\section{HER inhibitors for the treatment of epithelial ovarian cancer patients}

Standard frontline treatment of EOC patients consists of platinum- and taxane-based combination chemotherapy, most often carboplatin and paclitaxel. Following initial remission, patients may receive maintenance therapy to extend progression-free survival (PFS). After varying cycles of disease relapse and remission, EOC typically becomes platinum-resistant or refractory, at which point salvage therapy is often employed. Clinical trials are continuing to evaluate the role of HER-targeted therapeutics during each stage of cancer treatment, including use as postsalvage monotherapy after even palliative therapy options have been exhausted.

When evaluating clinical trials that incorporate HER-targeted therapeutics into the management of EOC patients, we must assess them within the context of the associated treatment regimens and patient populations. Induction therapy for EOC typically has a very high response rate (73-76\%) [6,8]; therefore, the addition of an HER-targeted therapeutic in 
the context of a clinical trial must further improve this response rate to be considered clinically meaningful. In contrast, salvage and postsalvage therapies have rapidly diminishing response rates, and the addition of an HER-targeted therapeutic need not induce a response in the majority of patients to be considered successful. Some argue that stable disease (SD) in response to a postsalvage therapy should be considered encouraging; indeed, certain modified indices of therapeutic response include a clinical benefit algorithm consisting of complete response to treatment (CR), partial response to treatment (PR) and $\mathrm{SD}$ rates. Furthermore, trials of HER inhibitors do not uniformly select for patients whose tumor expresses the therapeutic target. As shown in Supplementary Table 2, only a minority of HER inhibitor trials for the treatment of EOC required tumor expression of EGFR or HER2 as an inclusion criterion. However, even when evaluated with these modified indices, few clinical trials of HER inhibitors for the treatment of ovarian cancer have provided clear evidence of superior efficacy when compared with use of established chemotherapeutic treatment regimens alone. The results of published trials are summarized in Supplementary Table 2. Below, we discuss instances where ovarian cancer patient treatment regimens incorporating HER inhibitors have provided promising, albeit modest, indications of improved efficacy, as well as considerations for the design of future trials using these inhibitors.

Gefitinib (EGFR inhibitor)—Gefitinib plus chemotherapy has not proven superior to chemotherapy alone in any published study in terms of PFS and OS. However, several clinical trials of gefitinib monotherapy have shown modest efficacy. Baselga et al. reported the results of a Phase I trial of daily gefitinib (4-week cycles) for the treatment of advanced solid tumors, including EOC [118]. Of the 23 EOC patients enrolled in this study, one (4\%) achieved SD lasting 36 weeks. In a similar Phase I trial of daily gefitinib (2 weeks treatment and 2 weeks off treatment per cycle) for the treatment of patients with advanced solid tumors, one of eight (13\%) EOC patients achieved SD at 6 months [119]. In a Phase II trial of daily gefitinib (4-week cycles) for patients with advanced solid tumors judged to be EGFR positive (methods not presented), Vergote et al. reported that one of 33 (3\%) patients achieved PR and nine out of 33 (27\%) patients achieved SD at 2 months [120]. In a Phase II trial of daily gefitinib (4-week cycles) for the treatment of patients with persistent or recurrent EOC, three of 27 achieved SD (11\%) at 6 months, and one achieved PR (4\%) [121]. Interestingly, a mutation in the tyrosine kinase domain of EGFR, often observed in NSCLC, was observed in the one patient that achieved SD in this trial. In another Phase II trial of daily gefitinib (4-week cycles) for the treatment of refractory or recurrent EOC, nine of 24 (38\%) of patients achieved SD at 2 months [122]. Taken together, these Phase I and II clinical trials suggest that a subset of EOC patients benefit from gefitinib monotherapy.

Erlotinib (EGFR inhibitor)—Blank et al. described a three-stratum, Phase II study of daily erlotinib in combination with paclitaxel and carboplatin (3-week cycles, up to six cycles) as frontline therapy for patients with stage III or IV EOC; efficacy was initially assessed at 8 weeks of treatment [123]. Patients in each stratum received erlotinib as follows: stratum I received therapy after optimal debulking surgery; stratum II received therapy after suboptimal debulking surgery; and stratum III received neoadjuvant therapy 
prior to debulking. Among patients with optimally resected EOC, ten of 20 (50\%) demonstrated a CR (PR data not provided) and, of patients with suboptimally resected disease, three of 21 (14\%) had a CR. Among patients receiving neoadjuvant treatment, three of five $(60 \%)$ achieved a CR, and one of five $(20 \%)$ achieved SD. The addition of erlotinib to paclitaxel and carboplatin appears to be favorable for patients with optimally resected disease compared with paclitaxel and carboplatin treatment alone as frontline therapy (CR $28 \%$, PR $31 \%$ ) [124], but optimism must be tempered by the small number of patients enrolled in this trial and lack of randomization.

A Phase II trial of daily erlotinib and single agent carboplatin administered every 3 weeks among patients with recurrent EOC was described by Hirte et al.[125]. Among patients with platinum-resistant disease, $7 \%$ PR and 71\% SD were achieved. However, among patients with platinum-sensitive disease, this regimen achieved $10 \%$ CR, 47\% PR and $43 \%$ SD, which is comparable with the $11 \% \mathrm{CR}, 24 \% \mathrm{PR}$ and $39 \%$ SD achieved among EOC patients receiving single agent carboplatin every 3 weeks, as reported by Pfisterer et al.[126].

Finally, Gordon et al. described a Phase II study of daily erlotinib monotherapy (48 weeks or until disease progression or dose-limiting toxicity) for patients with advanced EOC. Erlotinib monotherapy resulted in PR and SD of 6 and 44\%, respectively, at 8 weeks $[127,128]$. Perplexingly, the only patients who achieved PR in response to erlotinib monotherapy had EGFR-negative ovarian tumors as determined by IHC.

Lapatinib (EGFR/HER2 inhibitor)—Daily lapatinib in combination with weekly topotecan has been evaluated in two Phase II trials of patients with recurrent EOC. In the first study (4-week cycles, up to eight cycles), Joly et al. reported that among patients with platinum-sensitive disease versus platinum-resistant disease, this combination yielded a $11 \%$ PR and 50\% SD, 0\% PR and 37\% SD, respectively [129]. Weroha et al., in contrast, enrolled only patients with platinum-resistant or refractory disease (4-week cycles, daily lapatinib and weekly topotecan 3 weeks out of 4 , up to 13 cycles); of 15 evaluable patients, one achieved PR (7\%) and three achieved SD (20\%) [130]. An ongoing Phase I/II clinical trial of daily lapatinib and weekly ( 3 weeks out of 4 per cycle) paclitaxel and carboplatin until disease progression in patients with relapsed stage III/IV EOC has shown $17 \% \mathrm{CR}$, $25 \% \mathrm{PR}$ and $46 \%$ SD rates at 8 weeks $[131,132]$.

Efficacy of lapatinib monotherapy for patients with persistent or recurrent EOC has been addressed in one Phase II trial. Garcia et al. reported an SD of $16 \%$, with no objective responses [133].

Cancertinib (EGFR/HER2/HER4/EGFRvIII inhibitor)—In a Phase II trial of daily cancertinib monotherapy ( 21 of 28 days per cycle, up to 18 cycles) for patients with relapsed EOC, $0 \% \mathrm{CR}, 0 \% \mathrm{PR}$ and 30\% SD were observed at 2 months [134]. No associations were observed between expression of HER family members and disease stability.

Vandetanib (EGFR/VEGFR2/ret inhibitor)_Annunziata et al. recently reported the results of a Phase II trial of daily vandetanib monotherapy (4-week cycles, up to 22 weeks) for patients with recurrent or refractory EOC [135]. Of the 12 enrolled patients, ten had 
platinum-resistant disease. No responses were noted among these 12 patients but four patients (33\%) did achieve SD at 16 weeks (one of two patients with platinum-sensitive EOC and three of ten patients with platinum-resistant disease).

Leflunomide (PDGFR/FGFR/EGFR inhibitor)-The PDGFR/FGFR/EGFR inhibitor leflunomide was tested as a weekly monotherapy for patients with advanced solid tumors in a Phase I study. In this study, one EOC patient achieved SD but the number of enrolled EOC patients was not specified [136].

In another Phase I/II trial of weekly leflunomide for patients with advanced EOC, NSCLC or prostate cancer, one of eight EOC patients (12.5\%) achieved PR lasting 22 months or longer [137]. In a follow up Phase II study of weekly leflunomide therapy (up to 11 weeks) for patients with advanced EOC, one patient of 15 (7\%) achieved PR at 6 weeks [138].

\section{Therapeutic antibodies}

Cetuximab (EGFR inhibitor)-Secord et al. reported the results of a Phase II trial of weekly cetuximab and carboplatin every 3 weeks (until disease progression or dose-limiting toxicity) for patients with relapsed, platinum-sensitive EOC [139]. This treatment regimen resulted in $12 \% \mathrm{CR}, 23 \% \mathrm{PR}$ and $31 \% \mathrm{SD}$, a modest improvement compared with the $6 \%$ $\mathrm{CR}$ and 25\% PR response rate to singleagent carboplatin reported by Pfisterer et al.[140]. However, median PFS was 9.1 versus 5.8 between these trials. Interestingly, Secord et al. noted the lack of correlation between tumor EGFR expression and response to this treatment regimen; of particular note, both patients whose tumors were judged to be EGFR negative had a clinical response.

Schilder et al. reported the results of a Phase II trial of weekly cetuximab monotherapy (3week cycles, up to 11 cycles) for the treatment of patients with persistent or recurrent EOC [141]. This patient population achieved a 0\% CR, 4\% PR and 36\% SD.

Matuzumab (EGFR inhibitor)-Seiden et al. reported the results of a Phase II trial of weekly matuzumab monotherapy (eight up to 30 weeks) for the treatment of patients with platinum-resistant EOC [142]. Of the 23 patients who completed at least 8 weeks of treatment, $0 \% \mathrm{CR}, 0 \% \mathrm{PR}$ and $21 \% \mathrm{SD}$ were observed.

Trastuzumab (HER2 inhibitor)-Ray-Coquard et al. reported the results of a Phase II study of paclitaxel, carboplatin and trastuzumab every 3 weeks (up to six cycles) for the treatment of patients with advanced EOC judged to be HER2-positive by IHC and/or flourescence in situ hybridization [143]. In this small trial of seven patients, the CR rate was $43 \%$ and the SD rate was $29 \%$. While little can be inferred from such a small treatment group, a $43 \% \mathrm{CR}$ rate using a platinum-containing regimen for platinum-resistant disease is impressive compared with previous reports [144,145].

In contrast, Bookman et al. reported the results of a Phase II trial of weekly trastuzumab monotherapy (up to 53 weeks) for the treatment of patients with recurrent or refractory EOC judged to be HER2-positive by IHC [146]. Of the 41 subjects treated, a CR of $2 \%$, PR of $5 \%$ and SD of $39 \%$ were reported. Recently, McAlpine et al. reported that one of three patients

Future Med Chem. Author manuscript; available in PMC 2015 October 26. 
with HER2-positive mucinous ovarian cancer experienced CR and another experienced PR following trastuzumab therapy with or without carboplatin [147]. Of note, none of the patients in the trial reported by Bookman et al. presented with mucinous EOC, so it was not possible to assess the effect of tumor histology on treatment response to trastuzumab in this study.

Pertuzumab (HER2 inhibitor)—Makhija et al. reported the results of a doubleblind, placebo-controlled Phase II trial of either gemcitabine plus placebo or gemcitabine plus pertuzumab ( 2 out of every 3 weeks until disease progression or dose-limiting toxicity) for the treatment of patients with platinum-resistant EOC [148]. Patients in the pertuzumab arm had an hazard ratio of $0.66(0.43,1.03 ; p=0.07)$ for disease progression compared with the placebo control group when adjusted for Eastern Coorperative Oncology Group performance status, number of prior platinum-containing regimens, and measurable disease (by Response Evaluation Criteria in Solid Tumors criteria), and median PFS was 2.9 versus 2.6 months. Patients in the pertuzumab treatment arm experienced 14\% PR, compared with $5 \%$ PR in the placebo arm. Low tumor expression of HER3 (as determined by quantitative real-time polymerase chain reaction) was associated with improved PFS in patients treated with pertuzumab (HR: 0.32 [0.17, 0.59; $p=0.0002]$ ). Among those patients in the lowest quartile of tumor HER3 expression, five of 13 patients demonstrated a clinical response to gemcitabine plus pertuzumab, while none of the 17 patients responded to gemcitabine plus placebo.

Similarly, Kaye et al. reported the findings of a Phase II trial for treatment of patients with platinum-sensitive EOC with pertuzumab plus carboplatin and, at the investigator's discretion, either paclitaxel or gemcitabine [149]. Patients were randomized to receive pertuzumab plus chemotherapy or chemotherapy alone. No differences in survival were observed between the four treatment arms. However, the authors did note an improvement in 6-12 month PFS in response to pertuzumab plus chemotherapy versus chemotherapy alone among patients with low tumor expression levels of HER3; however, this effect was not statistically significant (HR: 0.554; $\mathrm{p}=0.16$ ).

Agus et al. evaluated pertuzumab monotherapy every 3 weeks in a Phase I trial of patients with solid tumors, including three patients with EOC [150]. One of the three EOC patients achieved a PR and another achieved SD. Oddly, the tumor of the EOC patient with a PR did not overexpress HER2.

Gordon et al. described the results of a Phase II trial of pertuzumab every 3 weeks for the treatment of recurrent EOC [151]. A PR of 4\%, SD of 7\% for at least 6 months and SD of $6 \%$ for less than 6 months were observed. Assays for phosphorylated HER2 were performed in the 28 women in cohort 1 with fresh tumor biopsies. PR and SD rates of 4 and 7\%, respectively, were achieved, respectively. Although the median PFS was longer for patients $(\mathrm{n}=8)$ with HER2-positive tumors (20.9 weeks) versus those $(\mathrm{n}=20)$ with HER2-negative tumors (5.8 weeks), this effect was not statistically significant $(\mathrm{p}=0.14)$. 


\section{Summary \& conclusion}

In summary, a stark contrast exists between the in vitro evaluation of HER-targeted therapeutics and predicted clinical outcomes in EOC patients treated with HER-targeted therapeutics. One conclusion from these studies is that the stringency of cell line-based assays for predicting successful EOC treatment is insufficient for effective translation into the clinic. Several new animal models that mimic this disease have only recently been developed and have been underutilized in such preclinical drug studies. Moreover, most clinical trials using biologically targeted therapeutics have not optimally integrated potential predictive biomarkers and, critically, these drugs have largely been tested in heavily pretreated patients. One could argue that under these test conditions, finding responsive patients is not only unlikely, but may preclude the future testing of candidate drugs that may be highly effective in the treatment of this disease.

In spite of the serious limitations in previous studies, several HER-targeted therapeutics have shown promise in the frontline setting. As adaptive design and other emerging clinical trial strategies better suited to the testing of biologically targeted therapeutics are developed, optimal clinical trial design will increasingly be dependent on the discovery and development of positive predictive biomarkers for the effective stratification of patients for therapy. In this regard, analogous studies in both lung and breast cancer have resulted in the identification of significant subsets of patients who are responsive to EGFR/HER-targeted therapeutics $[152,153]$. Such patient selection strategies have been vital to the successful testing and approval of new treatment options for these patients, and serve as a useful paradigm for future studies in ovarian cancer. In general, greater investment in and emphasis on optimizing the testing of biologically targeted therapeutics for cancer patients is consonant with the notion that the next major advance in health care, in general, will be dependent on the advent of diagnostics-driven 'precision medicine' [154].

\section{Future perspective}

Despite decades of research and hundreds of clinical trials, late-stage EOC remains a largely intractable disease. While the introduction of biologically targeted therapeutics represents a true revolution in the treatment of some cancers, this revolution has not yet significantly impacted the treatment and survival outcome for ovarian cancer patients. Here, we speculate on the future role of HER inhibitors in the treatment and management of EOC.

\section{Evaluating HER inhibitor efficacy in epithelial ovarian cancer patient populations}

Since most biologically targeted therapeutics are tested in the context of heavily pretreated (and relapsed) patients, the clinical utility of HER-targeted therapeutics in patients with primary, previously untreated EOC has not been well studied. This shortcoming, in addition to the (relatively) low incidence of ovarian cancer, has 'left behind' this patient population in our increasing ability to more effectively treat patients with adult solid tumors with biologically targeted therapeutics. The apparent need for improvements in this area are illustrated by the high mortality rate for EOC patients, in spite of the relatively low incidence of this disease. 
For example, because the efficacy of monoclonal antibodies relies, at least in part, on activation of an uncompromised host immune system [155], heavy pretreatment of EOC patients with multiple regimens of immunosuppressive chemotherapy may limit the clinical efficacy of mAbs in this study population. The importance of an uncompromised immune system to the success of testing biologically targeted therapeutics has been highlighted by others [156]. Moreover, combinations of biologically targeted therapeutics may offer the best treatment strategy, but such studies, to date, have been limited in the study of improved treatment methods for EOC. The interpretation of the effectiveness of previous HERtargeted clinical trials must take all of these considerations into account.

Many clinical studies of HER-targeted therapeutics have addressed chemoresistant disease in a salvage setting, where CR and PR are increasingly unrealistic goals and where SD (prolonged PFS) might reasonably be considered a success. In this setting, CR and PR are increasingly unrealistic goals, and one might reasonably consider SD (prolonged PFS) a success. As shown in Supplementary Table 2, SD in response to HER-targeted therapy is common in this context; however, one must also consider the financial burden and quality of life of such treatment strategies. Nonetheless, the development of such strategies for breast cancer patients over the past decade has resulted in a significant increase in the 10-year survival rate for this disease, shifting disease treatment for this disease site to a chronic disease management strategy.

In this regard, while numerous trials of HER inhibitors in EOC have failed to reach 'target clinical efficacy,' we question whether these goals, in retrospect, were realistic. As one illustration of this point, the 'success' of the recent spate of bevacizumab trials for EOC treatment remains controversial. For example, the recent GOG 218 Phase III trial of frontline paclitaxel/carboplatin versus paclitaxel/carboplatin/bevacizumab versus paclitaxel/ carboplatin/bevacizumab plus bevacizumab maintenance reported PFS of 10.3, 11.2 and 14.1 months, respectively [157], and the improvement between paclitaxel/carboplatin versus paclitaxel/carboplatin/bevacizumab did not achieve statistical significance. On the other hand, Konner et al. reported good response rates for EOC patients treated with carboplatin, paclitaxel and cetuximab as frontline therapy [158]; in this study, PFS was 14.4 months, which compares favorably with the GOG 218 trial, though it must be stressed that this trial was not randomized. Erlotinib in combination with carboplatin and either paclitaxel [123] or docetaxel [159] appears as efficacious or slightly more so than chemotherapy alone and is well tolerated. Given that the difference in PFS of incorporating bevacizumab into frontline treatment in GOG 218 was a statistically insignificant 0.9 months, one could argue that HER-targeted inhibitors may be equally well justified for inclusion in frontline therapy trials. We propose here that HER inhibitors should be incorporated more often into trials of chemonaive EOC patients, rather than judging the clinical utility of these candidate drugs solely in heavily pretreated patient populations.

Indeed, cautious optimism may be justified for continued trials of HER inhibitors for the treatment of EOC. HER inhibitors, in general, are well tolerated (a notable exception being the combination of erlotinib and bevacizumab [160]). While these Phase II trials have not reached target efficacy, objective responses have, nevertheless, been observed in previous EOC trials using these drugs. As noted above, interesting response rates and clinical benefit 
were observed among patients treated with cytotoxic chemotherapy in concert with erlotinib, cexuximab, trastuzumab or pertuzumab. As described below, the challenge of effectively incorporating HER inhibitors into routine EOC treatment may depend on more reliable methods of predicting patient response to this new family of drugs.

\section{Predicting responsiveness to HER-targeted therapeutics for epithelial ovarian cancer}

ML Hensley, a GOG clinical oncologist, recently stated, "we will serve our patients best by designing trials that permit us to identify which patients have the highest likelihood of deriving a meaningful survival benefit from a novel agent" [161]. Despite the non-ideal setting for testing of most novel biologically targeted therapeutics, responders are regularly identified, even in the salvage setting, demonstrating that a significant subpopulation of ovarian cancers is dependent on EGFR/HER signaling. Given the enormous cost of clinical trials of novel therapeutics and the relatively small population of newly diagnosed ovarian cancer patients, it is imperative that we begin to use the results of previous correlative studies to identify prospective responders for biologically targeted therapeutics, as part of the study design. This concept is dramatically reinforced by statistical considerations regarding the early clinical trials on trastuzumab for the treatment of HER2-positive breast cancer; if no HER2 test had been available, and one assumed that HER2-negative patients had no benefit from treatment with trastuzumab, the sample size required for this study would have been 23,586 patients - 50-times more patients than were enrolled in this original trastuzumab study [162].

These early studies, as well as the past decade of research on other biologically targeted therapeutics, have taught us that it is unrealistic to expect any therapeutic to be a 'magic bullet' for all EOC patients. The true challenge in effectively translating these lessons into improved clinical practice will rely on the discovery and implementation of biomarkers capable of predicting response to novel HER-targeted therapeutics.

In this regard, the coupled dogmas that overexpression of a transforming oncogene is necessary for malignant transformation and, that levels of expression of a drugable target necessarily correlate with response, are rapidly eroding. While HER-targeted therapeutics have not been tested as extensively in ovarian cancer patients as they have been in other malignancies (i.e., non-small-cell lung cancer, head and neck cancer, colorectal cancer, pancreatic cancer and breast cancer, each of which is associated with at least one FDAapproved HER-targeted therapeutic), clues regarding treatment efficacy can be inferred from clinical studies in each of these malignancies. For example, Paik et al. recently demonstrated that patients with breast tumors expressing even low levels of HER2 (by central reference laboratory standards) may gain benefit from trastuzumab therapy [163]. Others have shown that responsiveness to cetuximab among CRC patients is negatively correlated with $K R A S$ and $B R A F$, rather than being a direct function of 'EGFR expression.' In fact, in most of these malignancies, EGFR/HER receptor expression levels, at least as currently measured, are not reliable as positive predictive markers of response [164-167].

Our group, therefore, initiated a meta-analysis aimed at correlating expression of HER expression in ovarian carcinoma-derived cell lines with response to HER-targeted therapeutics. Expression of HER family members [21] was classified as low, medium or 
high, and correlated with response (yes or no) to inhibitor as presented in Supplementary

Table 1. As presented in Table $2 \&$ Supplementary Table 3, we observed no statistically significant association between HER expression and responsiveness to any HER inhibitor. While conditional analyses suggest a possible association between high expression of HER2 and response to HER2-directed TKIs, similar associations were not noted between expression of EGFR and EGFR-directed TKIs or EGFR-directed antibodies, or between HER2 and HER2-directed antibodies. This observation is consonant with our observations, and those of others, demonstrating that HER expression does not, in general, predict ovarian cancer cell responsiveness to any HER-directed inhibitors, as discussed in greater detail below.

The lack of correlation between HER expression and drug responsiveness in vitro is perhaps counterintuitive and may be attributable to many factors. Technical factors include the broad range of methods (radioimmunoassay, immunoblot, ELISA, IHC, immunofluorescence and flow-assisted cell sorting) used to detect expression and/or activity of HER family members, including choice of antibodies and their related epitopes, methods of antigen retrieval and diverse methods of measuring cell proliferation, apoptosis, xenograft tumor growth, activation of receptor and downstream effectors. Clearly, there is no standardized method for HER detection or for measuring responsiveness to these inhibitors. Despite the lack of standardization for HER expression and/or related HER inhibitor assays, one must also consider the possibility that a lack of association between HER expression and response to inhibitor may be related to potential 'offtarget' mechanisms of activity, and/or complex facets of ovarian cancer cell biology; that is, does expression of an HER family member necessarily imply critical oncogenic function? Using a systems biology approach, Friedman and Perrimon describe cell signaling components as gradient of interconnected hubs, and observed that blockade of one signaling pathway may be overcome by compensatory signaling [168]. Alternatively, recent studies have demonstrated that HER-targeted therapeutics may cause subtle changes in a cell's phenotype without directly inhibiting cell growth in a variety of carcinoma-derived cell lines (including ovarian), including the induction of de novo sensitivity to other HER-targeted therapeutics $[117,169,170]$. In this review, we have noted the frequent lack of correlation between HER expression in malignant ovarian tumors (by IHC) and responsiveness to various HER-targeted therapeutics. For example, low objective response rates were observed in EOC patients with EGFR-positive tumors treated with matuzumab [142] or gefitinib [120] monotherapy, or HER2-positive tumors treated with trastuzumab monotherapy [146]. Furthermore, no correlation between EGFR expression and responsiveness to gefitinib plus carboplatin and paclitaxel chemotherapy was observed in patients with recurrent EOC by Pautier et al. [171173], and no correlation between HER expression and responsiveness to cancertinib monotherapy was observed Campos et al.[134].

\section{Identifying target pathways \& tissues of HER inhibitors}

Might the lack of association between HER expression and therapeutic responsiveness be explained in terms of function, rather than stoichiometry? In addition to the recent unexpected and controversial biomarker developments regarding EGFR in CRC [174,175], there is an interesting report by Matulonis and colleagues demonstrating that tumor HER3 
expression, and not HER2 expression, is associated with responsiveness to pertuzumab in patients with EOC [148]. In this regard, it is possible that noncanonical signaling functions of HER family members may influence responsiveness to therapy. HER signaling is not only regulated by association with other tyrosine kinases (e.g., Met, IGFR-I) [176,177], but also by interactions with various signaling adaptors (e.g., paxillin) and ECM/integrin interactions [178-180]; as such, HER proteins may signal independently of ligand, acting as a noncanonical transducer of signals by other kinases/cell-surface proteins. Finally, steady drug access to HER members can be influenced by steric associations between HERs and other proteins (e.g., integrins) and/or by perturbations in HER internalization kinetics [181], as shown by the recent finding that ligand-independent EGFR internalization is mediated via PKA/phosphatidic acid signaling [182]. The applicability of these noncanonical functions and/or regulators of HER family members in EOC remain understudied and, as such, represent a rich venue for future investigation.

In this regard, studies on the detailed mechanism of action of these drugs in the context of other potential biological targets for the treatment of EOC, such as BRCA1 or BRCA2, are limited. For example, the observation that $B R C A 1$ mutations have been correlated with reduced HER2 expression in breast cancer suggests these two signaling pathways share important convergence points that have not yet been identified [183]. The obvious potential for combined therapy using multiple biologically targeted therapeutics, as this field evolves, will require a better understanding of such convergence points in cancers such as breast and ovarian cancer.

Regardless of whether canonical or noncanonical HER signaling pathways are considered, recent controversies regarding the origin of EOC also lead us to question the utility and reliability of existing models of EOC. Recent evidence suggests that aggressive, high-grade EOC arises, at least in part, from secretory cells of the fallopian tube [184,185]. Drapkin et $a l$. have shown that a series of simple genetic manipulations of human primary cultures of fallopian tube secretory epithelial cells (including knockdown of p53 and protein phosphates $2 \mathrm{~A}$, and induced expression of hTERT, myc and constitutively active CDK4) results in a phenotype that recapitulates high grade EOC in vitro and also in xenograft models [186]. This provocative finding argues in favor of testing fallopian tube-derived models of EOC [187] during the preclinical testing phase of candidate drugs for the treatment of ovarian cancer. While a handful of reports have evaluated the expression of HER family members and ligands in human fallopian tube (including menstrual cycle-dependent expression) [188195], and provide an excellent foundation for future studies, renewed interest in the fallopian tube model for the origin of EOC will undoubtedly spark new investigations regarding the role of the HER family in the biology and pathobiology of the fallopian epithelium. Whatever the anatomical origin of EOC, few studies on the role of HER family members in EOC have considered how HER receptor signaling in non-malignant cells/tissues (e.g., stromal, vascular, immune and stem) may also mediate clinically beneficial and/or synergistic effects of combination therapies; for example, by regulating the epithelialmesenchymal transition of EOC cells, by stabilizing tumor microvasculature, by enhancing antitumor immunity and/or by sensitizing ovarian cancer stem cells. 


\section{Supplementary Material}

Refer to Web version on PubMed Central for supplementary material.

\section{Acknowledgments}

Financial \& competing interests disclosure

Grant support: JA Wilken is supported by the Marsha Rivkin Center for Ovarian Cancer Research. NJ Maihle is supported by NIH CA 53574 and a Senior Women in Medicine Professorship from Yale University School of Medicine. We thank K Darcy for her critical review of this manuscript, and K Wilken for expert assistance with artwork presented here.

No writing assistance was utilized in the production of this manuscript.

\section{Key Terms}

Epithelial
ovarian cancer

Biologically

targeted

cancer

therapeutics

EGFR/HER

Tyrosine

kinase

inhibitor
Most lethal form of gynecologic malignancy. Epithelial ovarian cancer is characterized by exquisite sensitivity and responsiveness to cytotoxic chemotherapy, typically followed by relapse with aggressive, chemoresistant disease. Newer models of highgrade serous ovarian carcinoma, the most common subtype of malignant epithelial ovarian cancer, may arise, at least in part, from secretory epithelial cells in the fallopian tube

Certain gene products, such as EGFR/HER, play a pivotal role in driving the growth and metastasis of cancer cells. Rational targeting of these key cancer cell growth pathways using protein-based 'biologic' therapeutics, such as antibodies, and small-molecule inhibitors, such as tyrosine kinase inhibitors, represent the vanguard of cancer therapy, and are in various stages of clinical development/practice

Prototypic receptor tyrosine kinase family, consisting of four distinct cell surface receptors: the epidermal growth factor receptor (EGFR)/ HER1, HER2, HER3 and HER4. All four members of the HER family are oncogenic in vitro and in vivo, and are frequently overexpressed and/or mutated in diverse solid tumors, where they play a critical role in both the etiology and progression of these malignancies Small molecule that reversibly or irreversibly binds within the ATPbinding pocket of a tyrosine kinase (e.g., EGFR/HER family members), reducing kinase activity

\section{References}

1. Siegel R, Naishadham D, Hemal A. Cancer statistics. CA Cancer J Clin. 2012; 62(1):10-29. [PubMed: 22237781]

2. Rodland KD, Maihle NJ. Searching for a system: the quest for ovarian cancer biomarkers. Cancer Biomark. 2011; 8(4-5):223-230. [PubMed: 22045355]

3. Barrena Medel NI, Wright JD, Herzog TJ. Targeted therapies in epithelial ovarian cancer. J Oncol. 2010 (Epub ahead of print). 10.1155/2010/314326 
4. Siwak DR, Carey M, Hennessy BT, et al. Targeting the epidermal growth factor receptor in epithelial ovarian cancer: current knowledge and future challenges. J Oncol. 2010 (Epub ahead of print). 10.1155/2010/568938

5. Zeineldin R, Muller CY, Stack MS, Hudson LG. Targeting the EGF receptor for ovarian cancer therapy. J Oncol. 2010 (Epub ahead of print). 10.1155/2010/414676

6. Vasey PA. Ovarian cancer: frontline standard treatment in 2008. Annu Oncol. 2008; 19(Suppl. 7):vii61-66.

7. Wakabayashi MT, Lin PS, Hakim AA. The role of cytoreductive/debulking surgery in ovarian cancer. J Natl Compr Canc Netw. 2008; 6(8):803-810. [PubMed: 18926091]

8. Lin H, Changchien CC. Management of relapsed/refractory epithelial ovarian cancer: current standards and novel approaches. Taiwan J Obstet Gynecol. 2007; 46(4):379-388. [PubMed: 18182343]

9. Marmor MD, Skaria KB, Yarden Y. Signal transduction and oncogenesis by ErbB/HER receptors. Int J Radiat Oncol Biol Phys. 2004; 58(3):903-913. [PubMed: 14967450]

10. Burgess AW, Cho HS, Eigenbrot C, et al. An open-and-shut case? Recent insights into the activation of EGF/ErbB receptors. Mol Cell. 2003; 12(3):541-552. [PubMed: 14527402]

11. Alroy I, Yarden Y. The ErbB signaling network in embryogenesis and oncogenesis: signal diversification through combinatorial ligand-receptor interactions. FEBS Lett. 1997; 410(1):8386. [PubMed: 9247128]

12. Citri A, Yarden Y. EGF-ERBB signalling: towards the systems level. Nat Rev Mol Cell Biol. 2006; 7(7):505-516. [PubMed: 16829981]

13. Muthuswamy SK, Gilman M, Brugge JS. Controlled dimerization of ErbB receptors provides evidence for differential signaling by homo- and heterodimers. Mol Cell Biol. 1999; 19(10):68456857. [PubMed: 10490623]

14. Normanno N, De Luca A, Bianco C, et al. Epidermal growth factor receptor (EGFR) signaling in cancer. Gene. 2006; 366(1):2-16. [PubMed: 16377102]

15. Olayioye MA, Neve RM, Lane HA, Hynes NE. The ErbB signaling network: receptor heterodimerization in development and cancer. Embo J. 2000; 19(13):3159-3167. [PubMed: 10880430]

16. Boerner JL, Danielsen A, Maihle NJ. Ligand-independent oncogenic signaling by the epidermal growth factor receptor: v-ErbB as a paradigm. Exp Cell Res. 2003; 284(1):111-121. [PubMed: 12648470]

17. Ramsauer VP, Pino V, Farooq A, Carothers Carraway CA, Salas PJ, Carraway KL. Muc4-ErbB2 complex formation and signaling in polarized CACO-2 epithelial cells indicate that Muc4 acts as an unorthodox ligand for ErbB2. Mol Cell Biol. 2006; 17(7):2931-2941.

18. Price-Schiavi SA, Andrechek E, Idris N, et al. Expression, location, and interactions of ErbB2 and its intramembrane ligand Muc4-(sialomucin complex) in rat mammary gland during pregnancy. $\mathrm{J}$ Cell Physiol. 2005; 203(1):44-53. [PubMed: 15499570]

19. Carraway KL, Carvajal ME, Li P, Carraway CA. ErbB2 and its ligand Muc4 (sialomucin complex) in rat lacrimal gland. Adv Exp Med Biol. 2002; 506(Pt A):289-295. [PubMed: 12613922]

20. Stern DF. Tyrosine kinase signalling in breast cancer: ErbB family receptor tyrosine kinases. Breast Cancer Res. 2000; 2(3):176-183. [PubMed: 11250707]

21. Lafky JM, Wilken JA, Baron AT, Maihle NJ. Clinical implications of the ErbB/epidermal growth factor (EGF) receptor family and its ligands in ovarian cancer. Biochim Biophys Acta. 2008; 1785(2):232-265. [PubMed: 18291115]

22. Basu A, Raghunath M, Bishayee S, Das M. Inhibition of tyrosine kinase activity of the epidermal growth factor (EGF) receptor by a truncated receptor form that binds to EGF: role for interreceptor interaction in kinase regulation. Mol Cell Biol. 1989; 9(2):671-677. [PubMed: 2785240]

23. Wilken JA, Baron AT, Foty RA, McCormick DJ, Maihle NJ. Identification of immunoreactive regions of homology between soluble epidermal growth factor receptor (sEGFR) and a5-integrin. Biochemistry. 2011; 50(20):4309-4321. [PubMed: 21491912]

24. Pedersen MW, Meltorn M, Damstrup L, Poulsen HS. The type III epidermal growth factor receptor mutation. Biological significance and potential target for anticancer therapy. Annu Oncol. 2001; 12(6):745-760. 
25. Moscatello DK, Holgado-Madruga M, Godwin AK, et al. Frequent expression of a mutant epidermal growth factor receptor in multiple human tumors. Cancer Res. 1995; 55(23):5536-5539. [PubMed: 7585629]

26. Lassus H, Sihto H, Leminen A, et al. Gene amplification, mutation, and protein expression of EGFR and mutations of ERBB2 in serous ovarian carcinoma. J Mol Med. 2006; 84(8):671-681. [PubMed: 16607561]

27. de Graeff P, Crijns AP, Ten Hoor KA, et al. The ErbB signalling pathway: protein expression and prognostic value in epithelial ovarian cancer. Br J Cancer. 2008; 99(2):341-349. [PubMed: 18628764]

28. Steffensen KD, Waldstrom M, Olsen DA, et al. Mutant epidermal growth factor receptor in benign, borderline, and malignant ovarian tumors. Clin Cancer Res. 2008; 14(11):3278-3282. [PubMed: 18519753]

29. Pedersen K, Angelini PD, Laos S, et al. A naturally occurring HER2 carboxy-terminal fragment promotes mammary tumor growth and metastasis. Mol Cell Biol. 2009; 29(12):3319-3331. [PubMed: 19364815]

30. Arribas J, Baselga J, Pedersen K, Parra-Palau JL. p95HER2 and breast cancer. Cancer Res. 2011; 71(5):1515-1519. [PubMed: 21343397]

31. Pupa SM, Menard S, Morelli D, Pozzi B, De Palo G, Colnaghi MI. The extracellular domain of the c-erbB-2 oncoprotein is released from tumor cells by proteolytic cleavage. Oncogene. 1993; 8(11): 2917-2923. [PubMed: 8105438]

32. Zabrecky JR, Lam T, McKenzie SJ, Carney W. The extracellular domain of p185/neu is released from the surface of human breast carcinoma cells, SK-BR-3. J Biol Chem. 1991; 266(3):17161720. [PubMed: 1671042]

33. Codony-Servat J, Albanell J, Lopez-Talavera JC, Arribas J, Baselga J. Cleavage of the HER2 ectodomain is a pervanadate-activable process that is inhibited by the tissue inhibitor of metalloproteases-1 in breast cancer cells. Cancer Res. 1999; 59(6):1196-1201. [PubMed: 10096547]

34. Anido J, Scaltriti M, Bech Serra JJ, et al. Biosynthesis of tumorigenic HER2 C-terminal fragments by alternative initiation of translation. EMBO J. 2006; 25(13):3234-3244. [PubMed: 16794579]

35. Liu CY, Yang W, Li JF, Sun SL, Shou CC. Effect of trastuzumab on tumor cell lines shedding high or low level of HER-2 ECD. Zhonghua Zhong Liu Za Zhi. 2007; 29(2):101-105. [PubMed: 17645842]

36. Christianson TA, Doherty JK, Lin YJ, et al. NH2-terminally truncated HER-2/neu protein: relationship with shedding of the extracellular domain and with prognostic factors in breast cancer. Cancer Res. 1998; 58(22):5123-5129. [PubMed: 9823322]

37. Maruo T, Ladines-Llave CA, Samoto T, et al. Expression of epidermal growth factor and its receptor in the human ovary during follicular growth and regression. Endocrinology. 1993; 132(2): 924-931. [PubMed: 8425504]

38. Prigent SA, Lemoine NR, Hughes CM, Plowman GD, Selden C, Gullick WJ. Expression of the cerbB-3 protein in normal human adult and fetal tissues. Oncogene. 1992; 7(7):1273-1278. [PubMed: 1377811]

39. Baron AT, Lafky JM, Suman VJ, et al. A preliminary study of serum concentrations of soluble epidermal growth factor receptor (sErbB1), gonadotropins, and steroid hormones in healthy men and women. Cancer Epidemiol Biomarkers Prev. 2001; 10(11):1175-1185. [PubMed: 11700266]

40. Lafky JM, Baron AT, Cora EM, et al. Serum soluble epidermal growth factor receptor concentrations decrease in postmenopausal metastatic breast cancer patients treated with letrozole. Cancer Res. 2005; 65(8):3059-3062. [PubMed: 15833834]

41. Berchuck A, Rodriguez GC, Kamel A, et al. Epidermal growth factor receptor expression in normal ovarian epithelium and ovarian cancer. I. Correlation of receptor expression with prognostic factors in patients with ovarian cancer. Am J Obstet Gynecol. 1991; 164(2):669-674. [PubMed: 1992720]

42. Foekens JA, van Putten WL, Portengen H, et al. Prognostic value of pS2 protein and receptors for epidermal growth factor (EGF-R), insulin-like growth factor-1 (IGF-1-R) and somatostatin (SS-R) 
in patients with breast and ovarian cancer. J Steroid Biochem Mol Biol. 1990; 37(6):815-821. [PubMed: 2178364]

43. Janinis J, Nakopoulou L, Panagos G, Davaris P. Immunohistochemical expression of EGF-R in malignant surface epithelial ovarian neoplasms (SEON). Eur J Gynaecol Oncol. 1994; 15(1):1923. [PubMed: 8206065]

44. Leng J, Lang J, Shen K, Guo L. Overexpression of p53, EGFR, c-erbB2 and c-erbB3 in endometrioid carcinoma of the ovary. Chin Med Sci J. 1997; 12(2):67-70. [PubMed: 11324501]

45. Psyrri A, Kassar M, Yu Z, et al. Effect of epidermal growth factor receptor expression level on survival in patients with epithelial ovarian cancer. Clin Cancer Res. 2005; 11(24 Pt 1):8637-8643. [PubMed: 16361548]

46. Skirnisdottir I, Seidal T, Sorbe B. A new prognostic model comprising p53, EGFR, and tumor grade in early stage epithelial ovarian carcinoma and avoiding the problem of inaccurate surgical staging. Int J Gynecol Cancer. 2004; 14(2):259-270. [PubMed: 15086725]

47. Baekelandt M, Kristensen GB, Trope CG, Nesland JM, Holm R. Epidermal growth factor receptor expression has no independent prognostic significance in advanced ovarian cancer. Anticancer Res. 1999; 19(5C):4469-4474. [PubMed: 10650794]

48. Elie C, Geay JF, Morcos M, et al. Lack of relationship between EGFR-1 immunohistochemical expression and prognosis in a multicentre clinical trial of 93 patients with advanced primary ovarian epithelial cancer (GINECO group). Br J Cancer. 2004; 91(3):470-475. [PubMed: 15226774]

49. Ferrandina G, Ranelletti FO, Lauriola L, et al. Cyclooxygenase-2 (COX-2), epidermal growth factor receptor (EGFR), and Her-2/ neu expression in ovarian cancer. Gynecol Oncol. 2002; 85(2): 305-310. [PubMed: 11972392]

50. Goff BA, Muntz HG, Greer BE, Tamimi HK, Gown AM. Oncogene expression: long-term compared with short-term survival in patients with advanced epithelial ovarian cancer. Obstet Gynecol. 1998; 92(1):88-93. [PubMed: 9649100]

51. Goff BA, Ries JA, Els LP, Coltrera MD, Gown AM. Immunophenotype of ovarian cancer as predictor of clinical outcome: evaluation at primary surgery and second-look procedure. Gynecol Oncol. 1998; 70(3):378-385. [PubMed: 9790791]

52. Lee CH, Huntsman DG, Cheang MC, et al. Assessment of Her-1, Her-2, And Her-3 expression and Her-2 amplification in advanced stage ovarian carcinoma. Int J Gynecol Pathol. 2005; 24(2):147152. [PubMed: 15782071]

53. Nielsen JS, Jakobsen E, Holund B, Bertelsen K, Jakobsen A. Prognostic significance of p53, Her-2, and EGFR overexpression in borderline and epithelial ovarian cancer. Int J Gynecol Cancer. 2004; 14(6):1086-1096. [PubMed: 15571614]

54. Raspollini MR, Castiglione F, Garbini F, et al. Correlation of epidermal growth factor receptor expression with tumor microdensity vessels and with vascular endothelial growth factor expression in ovarian carcinoma. Int J Surg Pathol. 2005; 13(2):135-142. [PubMed: 15864375]

55. Skirnisdottir I, Seidal T, Karlsson MG, Sorbe B. Clinical and biological characteristics of clear cell carcinomas of the ovary in FIGO stages I-II. Int J Oncol. 2005; 26(1):177-183. [PubMed: 15586238]

56. Slamon DJ, Godolphin W, Jones LA, et al. Studies of the HER-2/neu proto-oncogene in human breast and ovarian cancer. Science. 1989; 244(4905):707-712. [PubMed: 2470152]

57. Felip E, Del Campo JM, Rubio D, Vidal MT, Colomer R, Bermejo B. Overexpression of c-erbB-2 in epithelial ovarian cancer. Prognostic value and relationship with response to chemotherapy. Cancer. 1995; 75(8):2147-2152. [PubMed: 7697606]

58. Kupryjanczyk J, Madry R, Plisiecka-Halasa J, et al. TP53 status determines clinical significance of ERBB2 expression in ovarian cancer. Br J Cancer. 2004; 91(11):1916-1923. [PubMed: 15545967]

59. Meden H, Marx D, Roegglen T, Schauer A, Kuhn W. Overexpression of the oncogene c-erbB-2 (HER2/neu) and response to chemotherapy in patients with ovarian cancer. Int J Gynecol Pathol. 1998; 17(1):61-65. [PubMed: 9475194]

60. Nijman HW, Kenemans P, Poort-Keesom RJ, et al. Influence of chemotherapy on the expression of p53, HER-2/neu and proliferation markers in ovarian cancer. Eur J Obstet Gynecol Reprod Biol. 1999; 83(2):201-206. [PubMed: 10391533] 
61. Davidson B, Gotlieb WH, Ben-Baruch G, et al. E-Cadherin complex protein expression and survival in ovarian carcinoma. Gynecol Oncol. 2000; 79(3):362-371. [PubMed: 11104606]

62. Berchuck A, Kamel A, Whitaker R, et al. Overexpression of HER-2/neu is associated with poor survival in advanced epithelial ovarian cancer. Cancer Res. 1990; 50(13):4087-4091. [PubMed: 1972347]

63. Camilleri-Broet S, Hardy-Bessard AC, Le Tourneau A, et al. HER-2 overexpression is an independent marker of poor prognosis of advanced primary ovarian carcinoma: a multicenter study of the GINECO group. Annu Oncol. 2004; 15(1):104-112.

64. Lassus H, Leminen A, Vayrynen A, et al. ERBB2 amplification is superior to protein expression status in predicting patient outcome in serous ovarian carcinoma. Gynecol Oncol. 2004; 92(1):3139. [PubMed: 14751135]

65. Coronado Martin PJ, Fasero Laiz M, Garcia Santos J, Ramirez Mena M, Vidart Aragon JA. Overexpression and prognostic value of p53 and HER2/neu proteins in benign ovarian tissue and in ovarian cancer. Med Clin (Barc). 2007; 128(1):1-6. [PubMed: 17266884]

66. Hogdall EV, Christensen L, Kjaer SK, et al. Distribution of HER-2 overexpression in ovarian carcinoma tissue and its prognostic value in patients with ovarian carcinoma: from the Danish MALOVA Ovarian Cancer Study. Cancer. 2003; 98(1):66-73. [PubMed: 12833457]

67. Meden H, Marx D, Rath W, et al. Overexpression of the oncogene c-erb B2 in primary ovarian cancer: evaluation of the prognostic value in a Cox proportional hazards multiple regression. Int $\mathrm{J}$ Gynecol Pathol. 1994; 13(1):45-53. [PubMed: 7906681]

68. Tomic S, Ilic Forko J, Babic D, Sundov D, Kuret S, Andelinovic S. c-erbB-2, p53, and nm23 proteins as prognostic factors in patients with epithelial ovarian carcinoma. Croat Med J. 2003; 44(4):429-434. [PubMed: 12950146]

69. Verri E, Guglielmini P, Puntoni M, et al. HER2/neu oncoprotein overexpression in epithelial ovarian cancer: evaluation of its prevalence and prognostic significance. Clinical study. Oncology. 2005; 68(2-3):154-161. [PubMed: 16020953]

70. Protopapas A, Diakomanolis E, Bamias A, et al. The prognostic significance of the immunohistochemical expression of p53, bcl-2, c-erb B-2 and cathepsin-D in ovarian cancer patients receiving platinum with cyclophosphamide or paclitaxel chemotherapy. Eur J Gynaecol Oncol. 2004; 25(2):225-229. [PubMed: 15032288]

71. Raspollini MR, Amunni G, Villanucci A, et al. HER-2/neu and bcl-2 in ovarian carcinoma: clinicopathologic, immunohistochemical, and molecular study in patients with shorter and longer survival. Appl Immunohistochem Mol Morphol. 2006; 14(2):181-186. [PubMed: 16785787]

72. Surowiak P, Materna V, Kaplenko I, et al. Topoisomerase 1A, HER/2neu and Ki67 expression in paired primary and relapse ovarian cancer tissue samples. Histol Histopathol. 2006; 21(7):713720. [PubMed: 16598670]

73. Castellvi J, Garcia A, Rojo F, et al. Phosphorylated 4E binding protein 1: a hallmark of cell signaling that correlates with survival in ovarian cancer. Cancer. 2006; 107(8):1801-1811. [PubMed: 16983702]

74. Haldane JS, Hird V, Hughes CM, Gullick WJ. c-erbB-2 oncogene expression in ovarian cancer. J Pathol. 1990; 162(3):231-237. [PubMed: 2266460]

75. Kacinski BM, Mayer AG, King BL, Carter D, Chambers SK. NEU protein overexpression in benign, borderline, and malignant ovarian neoplasms. Gynecol Oncol. 1992; 44(3):245-253. [PubMed: 1347282]

76. Leeson SC, Morphopoulos G, Buckley CH, Hale RJ. c-erbB-2 oncogene expression in Stage I epithelial ovarian cancer. Br J Obstet Gynaecol. 1995; 102(1):65-67. [PubMed: 7833316]

77. Peethambaram PP, Cliby WA, Lubiniecki G, et al. Her-2/neu expression in ovarian cancer: preand postexposure to platinum chemotherapy. Gynecol Oncol. 2003; 89(1):99-104. [PubMed: 12694661]

78. Rodriguez-Burford C, Chhieng DC, Stockard CR, et al. p53 and erbB-2 are not associated in matched cases of primary and metastatic ovarian carcinomas. Dis Markers. 2003; 19(1):11-17. [PubMed: 14757942] 
79. Rubin SC, Finstad CL, Federici MG, Scheiner L, Lloyd KO, Hoskins WJ. Prevalence and significance of HER-2/neu expression in early epithelial ovarian cancer. Cancer. 1994; 73(5): 1456-1459. [PubMed: 7906607]

80. Rubin SC, Finstad CL, Wong GY, Almadrones L, Plante M, Lloyd KO. Prognostic significance of HER-2/neu expression in advanced epithelial ovarian cancer: a multivariate analysis. Am J Obstet Gynecol. 1993; 168(1 Pt 1):162-169. [PubMed: 8093588]

81. Singleton TP, Perrone T, Oakley G, et al. Activation of c-erbB-2 and prognosis in ovarian carcinoma. Comparison with histologic type, grade, and stage. Cancer. 1994; 73(5):1460-1466. [PubMed: 7906608]

82. Skirnisdottir I, Sorbe B, Seidal T. The growth factor receptors HER-2/neu and EGFR, their relationship, and their effects on the prognosis in early stage (FIGO I-II) epithelial ovarian carcinoma. Int J Gynecol Cancer. 2001; 11(2):119-129. [PubMed: 11328410]

83. van der Zee AG, Hollema H, Suurmeijer AJ, et al. Value of P-glycoprotein, glutathione Stransferase pi, c-erbB-2, and p53 as prognostic factors in ovarian carcinomas. J Clin Oncol. 1995; 13(1):70-78. [PubMed: 7799045]

84. Shen K, Lang J, Guo L. Overexpression of C-erbB3 in transitional cell carcinoma of the ovary. Zhonghua Fu Chan Ke Za Zhi. 1995; 30(11):658-661. [PubMed: 8745489]

85. Tanner B, Hasenclever D, Stern K, et al. ErbB-3 predicts survival in ovarian cancer. J Clin Oncol. 2006; 24(26):4317-4323. [PubMed: 16896008]

86. Gilmour LM, Macleod KG, McCaig A, Gullick WJ, Smyth JF, Langdon SP. Expression of erbB-4/ HER-4 growth factor receptor isoforms in ovarian cancer. Cancer Res. 2001; 61(5):2169-2176. [PubMed: 11280782]

87. Lafky, JM.; Greenwood, T.; Baron, AT.; Boardman, CH.; Cora, EM.; Maihle, NJ. Soluble ErbB receptors (sEGFR/sErbBs): serum biomarkers in breast and ovarian cancer. In: Diamandis, EP., editor. Tumor Markers: Physiology, Pathobiology, Technology and Clinical Applications. AACC Press; Chicago, IL, USA: 2002. p. 427-431.

88. Maihle NJ, Baron AT, Barrette BA, et al. EGF/ErbB receptor family in ovarian cancer. Cancer Treat Res. 2002; 107:247-258. [PubMed: 11775453]

89. Kim YS, Alarcon SV, Lee S, et al. Update on Hsp90 inhibitors in clinical trial. Current Top Med Chem. 2009; 9(15):1479-1492.

90. Fry DW, Kraker AJ, McMichael A, et al. A specific inhibitor of the epidermal growth factor receptor tyrosine kinase. Science. 1994; 265(5175):1093-1095. [PubMed: 8066447]

91. Schmiedel J, Blaukat A, Li S, Knochel T, Ferguson KM. Matuzumab binding to EGFR prevents the conformational rearrangement required for dimerization. Cancer Cell. 2008; 13(4):365-373. [PubMed: 18394559]

92. Franklin MC, Carey KD, Vajdos FF, Leahy DJ, de Vos AM, Sliwkowski MX. Insights into ErbB signaling from the structure of the ErbB2-pertuzumab complex. Cancer Cell. 2004; 5(4):317-328. [PubMed: 15093539]

93. Arnould L, Gelly M, Penault-Llorca F, et al. Trastuzumab-based treatment of HER2-positive breast cancer: an antibody-dependent cellular cytotoxicity mechanism? Br J Cancer. 2006; 94(2):259_ 267. [PubMed: 16404427]

94. Pegram M, Hsu S, Lewis G, et al. Inhibitory effects of combinations of HER-2/neu antibody and chemotherapeutic agents used for treatment of human breast cancers. Oncogene. 1999; 18(13): 2241-2251. [PubMed: 10327070]

95. Slamon DJ, Leyland-Jones B, Shak S, et al. Use of chemotherapy plus a monoclonal antibody against HER2 for metastatic breast cancer that overexpresses HER2. N Engl J Med. 2001; 344(11):783-792. [PubMed: 11248153]

96. Weiner LM, Holmes M, Adams GP, LaCreta F, Watts P, Garcia de Palazzo I. A human tumor xenograft model of therapy with a bispecific monoclonal antibody targeting c-erbB-2 and CD16. Cancer Res. 1993; 53(1):94-100. [PubMed: 8093231]

97. Weiner LM, Holmes M, Richeson A, et al. Binding and cytotoxicity characteristics of the bispecific murine monoclonal antibody 2B1. J Immunol. 1993; 151(5):2877-2886. [PubMed: 8103070] 
98. Kawaguchi Y, Kono K, Mimura K, Sugai H, Akaike H, Fujii H. Cetuximab induce antibodydependent cellular cytotoxicity against EGFR-expressing esophageal squamous cell carcinoma. Int J Cancer. 2007; 120(4):781-787. [PubMed: 17096332]

99. Kimura H, Sakai K, Arao T, Shimoyama T, Tamura T, Nishio K. Antibody-dependent cellular cytotoxicity of cetuximab against tumor cells with wild-type or mutant epidermal growth factor receptor. Cancer Sci. 2007; 98(8):1275-1280. [PubMed: 17498200]

100. Drebin JA, Link VC, Stern DF, Weinberg RA, Greene MI. Down-modulation of an oncogene protein product and reversion of the transformed phenotype by monoclonal antibodies. Cell. 1985; 41(3):697-706. [PubMed: 2860972]

101. Hurwitz E, Stancovski I, Sela M, Yarden Y. Suppression and promotion of tumor growth by monoclonal antibodies to ErbB-2 differentially correlate with cellular uptake. Proc Natl Acad Sci USA. 1995; 92(8):3353-3357. [PubMed: 7724565]

102. Klapper LN, Waterman H, Sela M, Yarden Y. Tumor-inhibitory antibodies to HER-2/ErbB-2 may act by recruiting c-Cbl and enhancing ubiquitination of HER-2. Cancer Res. 2000; 60(13): 3384-3388. [PubMed: 10910043]

103. Vincenzi B, Schiavon G, Silletta M, Santini D, Tonini G. The biological properties of cetuximab. Crit Rev Oncol Hematol. 2008; 68(2):93-106. [PubMed: 18676156]

104. Assoian RK, Zhu X. Cell anchorage and the cytoskeleton as partners in growth factor dependent cell cycle progression. Curr Opin Cell Biol. 1997; 9(1):93-98. [PubMed: 9013668]

105. Kokontis JM, Hay N, Liao S. Progression of LNCaP prostate tumor cells during androgen deprivation: hormone-independent growth, repression of proliferation by androgen, and role for p27Kip1 in androgen-induced cell cycle arrest. Mol Endocrinol. 1998; 12(7):941-953. [PubMed: 9658399]

106. Delord JP, Allal C, Canal M, et al. Selective inhibition of HER2 inhibits AKT signal transduction and prolongs disease-free survival in a micrometastasis model of ovarian carcinoma. Annu Oncol. 2005; 16(12):1889-1897.

107. Qiu L, Zhou C, Sun Y, et al. Crosstalk between EGFR and TrkB enhances ovarian cancer cell migration and proliferation. Int J Oncol. 2006; 29(4):1003-1011. [PubMed: 16964397]

108. Cao C, Lu S, Sowa A, et al. Priming with EGFR tyrosine kinase inhibitor and EGF sensitizes ovarian cancer cells to respond to chemotherapeutical drugs. Cancer Lett. 2008; 266(2):249-262. [PubMed: 18400375]

109. Ji C, Cao C, Lu S, et al. Curcumin attenuates EGF-induced AQP3 up-regulation and cell migration in human ovarian cancer cells. Cancer Chemother Pharmacol. 2008; 62(5):857-865. [PubMed: 18214481]

110. Zhou C, Qiu L, Sun Y, et al. Inhibition of EGFR/PI3K/AKT cell survival pathway promotes TSA's effect on cell death and migration in human ovarian cancer cells. Int J Oncol. 2006; 29(1): 269-278. [PubMed: 16773209]

111. Henic E, Sixt M, Hansson S, Hoyer-Hansen G, Casslen B. EGF-stimulated migration in ovarian cancer cells is associated with decreased internalization, increased surface expression, and increased shedding of the urokinase plasminogen activator receptor. Gynecol Oncol. 2006; 101(1):28-39. [PubMed: 16263158]

112. Yue $P$, Zhang X, Paladino D, et al. Hyperactive EGF receptor, Jaks and Stat 3 signaling promote enhanced colony-forming ability, motility and migration of cisplatin-resistant ovarian cancer cells. Oncogene. 2011 (Epub ahead of print). 10.1038/onc.2011.409

113. Caputo R, Bianco R, Damiano V, et al. ZD1839 ('Iressa'), a selective EGFR tyrosine kinase inhibitor, inhibits growth factor production and angiogenesis in human cancer cells. Annals Oncology. 2001; 12(Suppl. 4):93.

114. Park SJ, Kim MJ, Kim HB, et al. Trichostatin A sensitizes human ovarian cancer cells to TRAILinduced apoptosis by down-regulation of c-FLIPL via inhibition of EGFR pathway. Biochem Pharmacol. 2009; 77(8):1328-1336. [PubMed: 19426671]

115. Canal PR Sr, Delord JP, Quideau S, et al. Cross-talk between PTEN and RhoB drives biological effect of trastuzumab in ovarian cancer. Proc Am Assoc Cancer Res. 2009; 50 (Abstract 1843). 
116. Mukherji M, Brill LM, Ficarro SB, Hampton GM, Schultz PG. A phosphoproteomic analysis of the ErbB2 receptor tyrosine kinase signaling pathways. Biochemistry. 2006; 45(51):15529_ 15540. [PubMed: 17176074]

117. Wilken JA, Webster KT, Maihle NJ. Trastuzumab sensitizes ovarian cancer cells to EGFRtargeted therapeutics. J Ovarian Res. 2010; 3(1):7. [PubMed: 20346177]

118. Baselga J, Rischin D, Ranson M, et al. Phase I safety, pharmacokinetic, and pharmacodynamic trial of ZD1839, a selective oral epidermal growth factor receptor tyrosine kinase inhibitor, in patients with five selected solid tumor types. J Clin Oncol. 2002; 20(21):4292-4302. [PubMed: 12409327]

119. Ranson M, Hammond LA, Ferry D, et al. ZD1839, a selective oral epidermal growth factor receptor-tyrosine kinase inhibitor, is well tolerated and active in patients with solid, malignant tumors: results of a Phase I trial. J Clin Oncol. 2002; 20(9):2240-2250. [PubMed: 11980995]

120. Vergote IB, Humblet Y, van Cutsem E, et al. A multicenter Phase II trial of gefitinib $500 \mathrm{mg} / \mathrm{day}$ in 193 patients with advanced epidermal growth factor receptor-positive solid tumors who had failed previous chemotherapy: interim data. J Clin Oncol. 2005; 23(16S):3162.

121. Schilder RJ, Sill MW, Chen X, et al. Phase II study of gefitinib in patients with relapsed or persistent ovarian or primary peritoneal carcinoma and evaluation of epidermal growth factor receptor mutations and immunohistochemical expression: a gynacologic oncology group study. Clin Cancer Res. 2005; 11(15):5539-5548. [PubMed: 16061871]

122. Posadas EM, Liel MS, Kwitkowski V, et al. A Phase II and pharmacodynamic study of gefitinib in patients with refractory or recurrent epithelial ovarian cancer. Cancer. 2007; 109(7):13231330. [PubMed: 17330838]

123. Blank SV, Christos P, Curtin JP, et al. Erlotinib added to carboplatin and paclitaxel as frist-line treatment of ovarian cancer: a Phase II study based on surgical reassessment. Gynecol Oncol. 2010; 119(3):451-456. [PubMed: 20837357]

124. Vasey PA, Jayson GC, Gordon A, et al. Phase III randomized trial of docetaxel-carboplatin versus paclitaxel-carboplatin as first-line chemotherapy for ovarian carcinoma. J Natl Cancer Inst. 2004; 96(22):1682-1691. [PubMed: 15547181]

125. Hirte H, Oza A, Swenerton K, et al. A Phase II study of erlotinib (OSI-774) given in combination with carboplatin in patients with recurrent epithelial ovarian cancer (NCIC CTG IND.149). Gynecol Oncol. 2010; 118(3):308-312. [PubMed: 20646751]

126. Pfisterer J, Plante M, Vergote I, et al. Gemcitabine plus carboplatin compared with carboplatin in patients with platinum-sensitive recurrent ovarian cancer: an intergroup trial of the AGO-OVAR, the NCIC CTG, and the EORTC GCG. J Clin Oncol. 2006; 24(29):4699-4707. [PubMed: 16966687]

127. Gordon AN, Finkler N, Edwards RP, et al. Efficacy and safety of erlotinib HCl, an epidermal growth factor receptor (HER1/EGFR) tyrosine kinase inhibitor, in patients with advanced ovarian carcinoma: results from a Phase II multicenter study. Int J Gynecol Cancer. 2005; 15(5):785-792. [PubMed: 16174225]

128. Finkler N, Gordon A, Crozier M, et al. Phase 2 evaluation of OSI-774, a potent oral antagonist of the EGFR-TK in patients with advanced ovarian carcinoma. Proc Am Soc Clin Oncol. 2001; 20:831.

129. Joly F, Weber B, Pautier P, et al. Combined topotecan and lapatinib in patients with early recurrent ovarian or peritoneal cancer after first line of platinum-based chemotherapy: A french FEDEGYN-FNCLCC Phase II trial. J Clin Oncol. 2009; 27(15s) Abstract 5555.

130. Weroha SJ, Oberg AL, Ziegler KL, et al. Phase II trial of lapatinib and topotecan (LapTop) in patients with platinum-refractory/resistant ovarian and primary peritoneal carcinoma. Gynecol Oncol. 2011; 122(1):116-120. [PubMed: 21514634]

131. Rivkin, SE.; Moon, J.; Muller, C.; Iriarte, D.; Arthur, J.; Reid, H. A Phase I/II study of lapatinib plus carboplatin and paclitaxel in stage III or IV relapsed ovarian cancer patients or stage IV breast cancer patients; 7th Biennial Ovarian Cancer Res Symposium; Seattle, WA, USA. 25 October 2008;

132. Rivkin SE, Muller C, Iriarte D, Arthur J, Canoy A, Reid H. Phase I/II lapatinib plus carboplatin and paclitaxel in stage III or IV relapsed ovarian cancer patients. J Clin Oncol. 2008; 26:5556. 
133. Garcia AA, Sill MW, Lankes HA, et al. A Phase II evaluation of lapatinib in the treatment of persistent or recurrent epithelial ovarian or primary peritoneal carcinoma: a gynecologic oncology group study. Gynecol Oncol. 2011; 124(3):569-574. [PubMed: 22037316]

134. Campos S, Hamid O, Seiden MV, et al. Multicenter, randomized Phase II trial of oral CI-1033 for previously treated advanced ovarian cancer. J Clin Oncol. 2005; 23(24):5597-5604. [PubMed: 16110019]

135. Annunziata CM, Walker AJ, Minasian L, et al. Vandetanib, designed to inhibit VEGFR2 and EGFR signaling, had no clinical activity as monotherapy for recurrent ovarian cancer and no detectable modulation of VEGFR2. Clin Cancer Res. 2010; 16(2):664-672. [PubMed: 20068097]

136. VanUmmersen L, MNess E, Goldstein DJ, et al. A Phase I trial of SU101 in patients with solid tumors. Proc Am Soc Clin Oncol. 1997; 15:740.

137. Rosen L, Lopez AM, Mulay M, et al. A Phase I/II study of SU101 in patients with ovarian, prostate, and non-small cell lung cancers. Proc Am Soc Clin Oncol. 1997; 15:739.

138. Chap L, Chachoua A, Lopez A, DePaoli A, Hannah AL. A Phase II study of SU101 in patents with advanced ovarian cancer. Proc Am Soc Clin Oncol. 1999; 17:1437.

139. Secord AA, Blessing JA, Armstrong DK, et al. Phase II trial of cetuximab and carboplatin in relapsed platinum-sensitive ovarian cancer and evaluation of epidermal growth factor receptor expression: a Gynecol. Oncol. Group study. Gynecol Oncol. 2008; 108(3):493-499. [PubMed: 18191993]

140. Pfisterer J, Vergote I, Du Bois A, Eisenhauer E. Combination therapy with gemcitabine and carboplatin in recurrent ovarian cancer. Int J Gynecol Cancer. 2005; 15(Suppl. 1):36-41. [PubMed: 15839957]

141. Schilder RJ, Pathak HB, Lokshin AE, et al. Phase II trial of single agent cetuximab in patients with persistent or recurrent epithelial ovarian or primary peritoneal carcinoma with the potential for dose escalation to rash. Gynecol Oncol. 2009; 113(1):21-27. [PubMed: 19162309]

142. Seiden MV, Burris HA, Matulonis U, et al. A Phase II trial of EMD72000 (matuzumab), a humanized anti-EGFR monoclonal antibody, in patients with platinum-resistant ovarian and primary peritoneal malignancies. Gynecol Oncol. 2007; 104(3):727-731. [PubMed: 17126894]

143. Ray-Coquard I, Guastalla JP, Allouache D, et al. HER2 overexpression/amplification and trastuzumab treatment in advanced ovarian cancer: a GINECO Phase II study. Clin Ovarian Cancer. 2008; 1(1):54-59.

144. Gore ME, Fryatt I, Wiltshaw E, Dawson T. Treatment of relapsed carcinoma of the ovary with cisplatin or carboplatin following initial treatment with these compounds. Gynecol Oncol. 1990; 36(2):207-211. [PubMed: 2404837]

145. Markman M, Rothman R, Hakes T, et al. Second-line platinum therapy in patients with ovarian cancer previously treated with cisplatin. J Clin Oncol. 1991; 9(3):389-393. [PubMed: 1999708]

146. Bookman MA, Darcy KM, Clarke-Pearson D, Boothby RA, Horowitz IR. Evaluation of monoclonal humanized anti-HER2 antibody, trastuzumab, in patients with recurrent or refractory ovarian or primary peritoneal carcinoma with overexpression of HER2: a Phase II trial of the Gynecol. Oncol. Group. J Clin Oncol. 2003; 21(2):283-290. [PubMed: 12525520]

147. McAlpine JN, Wiegand KC, Vang R, et al. HER2 overexpression and amplification is present in a subset of ovarian mucinous carcinomas and can be targeted with trastuzumab therapy. BMC Cancer. 2009; 9:433. [PubMed: 20003286]

148. Makhija S, Amler LC, Glenn D, et al. Clinical activity of gemcitabine plus pertuzumab in platinum-resistant ovarian cancer, fallopian tube cancer, or primary peritoneal cancer. J Clin Oncol. 2009; 28(7):1215-1223. [PubMed: 19901115]

149. Kaye SB, Poole CJ, Bidzinksi M, et al. A randomised Phase II study evaluating the combination of carboplatin-based chemotherapy with pertuzumab $(\mathrm{P})$ versus carboplatin-based therapy alone in patients with relapsed, platinum sensitive ovarian cancer. J Clin Oncol. 2008; 26:5520.

150. Agus DB, Gordon MS, Taylor C, et al. Phase I clinical study of pertuzumab, a novel HER dimerization inhibitor, in patients with advanced cancer. J Clin Oncol. 2005; 23(11):2534-2543. [PubMed: 15699478] 
151. Gordon MS, Matei D, Aghajanian C, et al. Clinical activity of pertuzumab (rhuMAb 2C4), a HER dimerization inhibitor, in advanced ovarian cancer: potential predictive relationship with tumor HER2 activation status. J Clin Oncol. 2006; 24(26):4324-4332. [PubMed: 16896006]

152. Herbst RS, Lippman SM. Molecular signatures of lung cancer - toward personalized therapy. N Engl J Med. 2007; 356(1):76-78. [PubMed: 17202459]

153. Goldhirsch A, Wood WC, Coates AS, Gelber RD, Thurlimann B, Senn HJ. Strategies for subtypes-dealing with the diversity of breast cancer: highlights of the St. Gallen International Expert Consensus on the Primary Therapy of Early Breast Cancer 2011. Annu Oncol. 2011; 22(8):1736-1747.

154. Christensen, CM. The Innovator's Prescription: a Disruptive Solution for Health Care. Christensen, CM.; Grossman, JH.; Hwang, J., editors. McGraw-Hill; NY, USA: 2009.

155. Clynes R, Takechi Y, Moroi Y, Houghton A, Ravetch JV. Fc receptors are required in passive and active immunity to melanoma. Proc Natl Acad Sci USA. 1998; 95(2):652-656. [PubMed: 9435247]

156. Thaker PH, Han LY, Kamat AA, et al. Chronic stress promotes tumor growth and angiogenesis in a mouse model of ovarian carcinoma. Nat Med. 2006; 12(8):939-944. [PubMed: 16862152]

157. Burger RA, Brady MF, A BM, et al. Phase III trial of bevacizumab (BEV) in the primary treatment of advanced epithelial ovarian cancer (EOC), primary peritoneal cancer (PPC), and fallopian tube cancer (FTC): a Gynecol. Oncol. Group study. Oncology. 2010; 79(1-2):98-104. [PubMed: 21079407]

158. Konner J, Schilder RJ, DeRosa FA, et al. A Phase II study of cetuximab/paclitaxel/carboplatin for the initial treatment of advanced-stage ovarian, primary peritoneal, or fallopian tube cancer. Gynecol Oncol. 2008; 110(2):140-145. [PubMed: 18554700]

159. Vasey PA, Gore M, Wilson R, et al. A Phase Ib trial of docetaxel, carboplatin and erlotinib in ovarian, fallopian tube and primary peritoneal cancers. Br J Cancer. 2008; 98(11):1774-1780. [PubMed: 18506181]

160. Nimeiri HS, Oza AM, Morgan RJ, et al. Efficacy and safety of bevacizumab plus erlotinib for patients with recurrent ovarian, primary peritoneal, and fallopian tube cancer: a trial of the Chicago, PMH, and California Phase II Consortia. Gynecol Oncol. 2008; 110(1):49-55. [PubMed: 18423560]

161. Hensley ML. Big costs for little gain in ovarian cancer. J Clin Oncol. 2011; 29(10):1230-1232. [PubMed: 21383287]

162. Jorgensen JT, Nielsen KV, Ejlertsen B. Pharmacodiagnostics and targeted therapies - a rational approach for individualizing medical anticancer therapy in breast cancer. Oncologist. 2007; 12(4):397-405. [PubMed: 17470682]

163. Paik S, Kim C, Wolmark N. HER2 status and benefit from adjuvant trastuzumab in breast cancer. New Engl J Med. 2008; 358(13):1409-1411. [PubMed: 18367751]

164. Bengala C, Bettelli S, Bertolini F, et al. Epidermal growth factor receptor gene copy number, Kras mutation and pathological response to preoperative cetuximab, 5-FU and radiation therapy in locally advanced rectal cancer. Annu Oncol. 2008; 20(3):469-474.

165. Benvenuti S, Sartore-Bianchi A, Di Nicolantonio F, et al. Oncogenic activation of the RAS/RAF signaling pathway impairs the response of metastatic colorectal cancers to anti-epidermal growth factor receptor antibody therapies. Cancer Res. 2007; 67(6):2643-2648. [PubMed: 17363584]

166. Frattini M, Saletti P, Romagnani E, et al. PTEN loss of expression predicts cetuximab efficacy in metastatic colorectal cancer patients. Br J Cancer. 2007; 97(8):1139-1145. [PubMed: 17940504]

167. Karapetis CS, Khambata-Ford S, Jonker DJ, et al. K-ras mutations and benefit from cetuximab in advanced colorectal cancer. N Engl J Med. 2008; 359(17):1757-1765. [PubMed: 18946061]

168. Friedman A, Perrimon N. Genetic screening for signal transduction in the era of network biology. Cell. 2007; 128(2):225-231. [PubMed: 17254958]

169. Jain A, Penuel E, Mink S, et al. HER kinase axis receptor dimer partner switching occurs in response to EGFR tyrosine kinase inhibition despite failure to block cellular proliferation. Cancer Res. 2010; 70(5):1989-1999. [PubMed: 20160029] 
170. Narayan M, Wilken JA, Harris LN, Baron AT, Kimbler KD, Maihle NJ. Trastuzumab-induced HER reprogramming in 'resistant' breast carcinoma cells. Cancer Res. 2009; 69(6):2191-2194. [PubMed: 19276389]

171. Domont J, Besse B, Valent A, et al. Assessment of response to gefitinib in combination with chemotherapy in ovarian cancer according to EGFR expresion in monocentric study. Annu Oncol. 2006; 17(Suppl. 9):176.

172. Lacroix L, Pautier P, Duvillard P, et al. Response of ovarian carcinomas to gefitinib-carboplatinpaclitaxel-combination is not associated with EGFR kinase domain somatic mutations. Int $\mathbf{J}$ Cancer. 2006; 118(4):1068-1069. [PubMed: 16152583]

173. Pautier P, Joly F, Kerbrat P, et al. Phase II study of gefitinib- $n$ combination with paclitaxel (P) and carboplatin $(\mathrm{C})$ as second-line therapy for ovarian, tubal or peritoneal adenocarcinoma (1839IL/0074). Gynecol Oncol. 2010; 116(2):157-162. [PubMed: 20109725]

174. Siena S, Sartore-Bianchi A, Di Nicolantonio F, Balfour J, Bardelli A. Biomarkers predicting clinical outcome of epidermal growth factor receptor-targeted therapy in metastatic colorectal cancer. J Natl Cancer Inst. 2009; 101(19):1308-1324. [PubMed: 19738166]

175. Wilken JA, Baron AT, Maihle NJ. The epidermal growth factor receptor conundrum. Cancer. 2010; 117(11):2358-2360. [PubMed: 24048781]

176. van der Veeken J, Oliveira S, Schiffelers RM, Storm G, van Bergen En Henegouwen PM, Roovers RC. Crosstalk between epidermal growth factor receptor- and insulin-like growth factor-1 receptor signaling: implications for cancer therapy. Curr Cancer Drug Targets. 2009; 9(6):748-760. [PubMed: 19754359]

177. Mueller KL, Yang ZQ, Haddad R, Ethier SP, Boerner JL. EGFR/Met association regulates EGFR TKI resistance in breast cancer. J Mol Signal. 2010; 5:8. [PubMed: 20624308]

178. Bill HM, Knudsen B, Moores SL, et al. Epidermal growth factor receptor-dependent regulation of integrin-mediated signaling and cell cycle entry in epithelial cells. Mol Cell Biol. 2004; 24(19): 8586-8599. [PubMed: 15367678]

179. Marcoux N, Vuori K. EGF receptor mediates adhesion-dependent activation of the Rac GTPase: a role for phosphatidylinositol 3-kinase and Vav2. Oncogene. 2003; 22(38):6100-6106. [PubMed: 12955089]

180. Tiganis T, Kemp BE, Tonks NK. The protein-tyrosine phosphatase TCPTP regulates epidermal growth factor receptor-mediated and phosphatidylinositol 3-kinase-dependent signaling. J Biol Chem. 1999; 274(39):27768-27775. [PubMed: 10488121]

181. Caswell PT, Chan M, Lindsay AJ, McCaffrey MW, Boettiger D, Norman JC. Rab-coupling protein coordinates recycling of alpha5beta1 integrin and EGFR1 to promote cell migration in 3D microenvironments. J Cell Biol. 2008; 183(1):143-155. [PubMed: 18838556]

182. Norambuena A, Metz C, Jung JE, et al. Phosphatidic acid induces ligand-independent epidermal growth factor receptor endocytic traffic through PDE4 activation. Mol Cell Biol. 2010; 21(16): 2916-2929.

183. Grushko TA, Blackwood MA, Schumm PL, et al. Molecular-cytogenetic analysis of HER-2/ neu gene in BRCA1-associated breast cancers. Cancer Res. 2002; 62(5):1481-1488. [PubMed: 11888924]

184. Lee Y, Miron A, Drapkin R, et al. A candidate precursor to serous carcinoma that originates in the distal fallopian tube. J Pathol. 2007; 211(1):26-35. [PubMed: 17117391]

185. Folkins AK, Jarboe EA, Saleemuddin A, et al. A candidate precursor to pelvic serous cancer (p53 signature) and its prevalence in ovaries and fallopian tubes from women with BRCA mutations. Gynecol Oncol. 2008; 109(2):168-173. [PubMed: 18342932]

186. Karst AM, Levanon K, Drapkin R. Modeling high-grade serous ovarian carcinogenesis from the fallopian tube. Proc Natl Acad Sci USA. 2011; 108(18):7547-7552. [PubMed: 21502498]

187. Seton-Rogers S. Ovarian cancer: model building. Nat Rev Cancer. 2011; 11(6):386. [PubMed: 21593788]

188. Wang DP, Fujii S, Konishi I, et al. Expression of c-erbB-2 protein and epidermal growth factor receptor in normal tissues of the female genital tract and in the placenta. Virchows Arch A Pathol Anat Histopathol. 1992; 420(5):385-393. [PubMed: 1375794] 
189. Lei ZM, Rao CV. Expression of epidermal growth factor (EGF) receptor and its ligands, EGF and transforming growth factor-alpha, in human fallopian tubes. Endocrinology. 1992; 131(2):947957. [PubMed: 1639032]

190. el-Danasouri I, Frances A, Westphal LM. Immunocytochemical localization of transforming growth factor-alpha and epidermal growth factor receptor in human fallopian tubes and cumulus cells. Am J Reprod Immunol. 1993; 30(2-3):82-87. [PubMed: 8311934]

191. Chegini N, Zhao Y, McLean FW. Expression of messenger ribonucleic acid and presence of immunoreactive proteins for epidermal growth factor (EGF), transforming growth factor alpha (TGF alpha) and EGF/TGF alpha receptors and 125I-EGF binding sites in human fallopian tube. Biol Reprod. 1994; 50(5):1049-1058. [PubMed: 8025160]

192. Adachi K, Kurachi H, Homma H, et al. Estrogen induces epidermal growth factor (EGF) receptor and its ligands in human fallopian tube: involvement of EGF but not transforming growth factoralpha in estrogen-induced tubal cell growth in vitro. Endocrinology. 1995; 136(5):2110-2119. [PubMed: 7720660]

193. Adachi K, Kurachi H, Adachi H, et al. Menstrual cycle specific expression of epidermal growth factor receptors in human fallopian tube epithelium. J Endocrinol. 1995; 147(3):553-563. [PubMed: 8543926]

194. Smotrich DB, Stillman RJ, Widra EA, et al. Immunocytochemical localization of growth factors and their receptors in human preembryos and Fallopian tubes. Hum Reprod. 1996; 11(1):184190. [PubMed: 8671183]

195. Sun XX, Gemzell-Danielsson K, Li HZ, Stabi B, Stavreus-Evers A. Expression of heparinbinding epidermal growth factor-like growth factor and its receptors in the human fallopian tube and endometrium after treatment with mifepristone. Fertil Steril. 2006; 85(1):171-178. [PubMed: 16412750]

196. Pegues JC, Kannan B, Stromberg K. ErbB receptor expression and growth response to heregulin beta 1 in five ovarian carcinoma lines. Int J Oncol. 1999; 14(6):1169-1176. [PubMed: 10339675]

197. Beerli RR, Graus-Porta D, Woods-Cook K, Chen X, Yarden Y, Hynes NE. Neu differentiation factor activation of ErbB-3 and ErbB-4 is cell specific and displays a differential requirement for ErbB-2. Mol Cell Biol. 1995; 15(12):6496-6505. [PubMed: 8524214]

198. Lewis GD, Figari I, Fendly B, et al. Differential responses of human tumor cell lines to antip185HER2 monoclonal antibodies. Cancer Immunol Immunother. 1993; 37(4):255-263. [PubMed: 8102322]

199. Bacus SS, Gudkov AV, Zelnick CR, et al. Neu differentiation factor (heregulin) induces expression of intercellular adhesion molecule 1: implications for mammary tumors. Cancer Res. 1993; 53(21):5251-5261. [PubMed: 8106145]

200. Dai Q, Ling YH, Lia M, et al. Enhanced sensitivity to the HER1/epidermal growth factor receptor tyrosine kinase inhibitor erlotinib hydrochloride in chemotherapy-resistant tumor cell lines. Clin Cancer Res. 2005; 11(4):1572-1578. [PubMed: 15746062]

201. Peles E, Ben-Levy R, Tzahar E, Liu N, Wen D, Yarden Y. Cell-type specific interaction of Neu differentiation factor (NDF/heregulin) with Neu/HER-2 suggests complex ligand-receptor relationships. EMBO J. 1993; 12(3):961-971. [PubMed: 8096177]

202. Sewell JM, Macleod KG, Ritchie A, Smyth JF, Langdon SP. Targeting the EGF receptor in ovarian cancer with the tyrosine kinase inhibitor ZD 1839 ('Iressa®'). Br J Cancer. 2002; 86(3): 456-462. [PubMed: 11875715]

203. Tang HJ, Jin X, Wang S, et al. A small molecule compound inhibits AKT pathway in ovarian cancer cell lines. Gynecol Oncol. 2006; 100(2):308-317. [PubMed: 16209885]

204. Coley HM, Shotton CF, Ajose-Adeogun A, Modjtahedi H, Thomas H. Receptor tyrosine kinase (RTK) inhibition is effective in chemosensitising EGFR-expressing drug resistant human ovarian cancer cell lines when used in combination with cytotoxic agents. Biochem Pharmacol. 2006; 72(8):941-948. [PubMed: 16934227]

205. Gilmour LM, Macleod KG, McCaig A, et al. Neuregulin expression, function, and signaling in human ovarian cancer cells. Clin Cancer Res. 2002; 8(12):3933-3942. [PubMed: 12473609]

Future Med Chem. Author manuscript; available in PMC 2015 October 26. 
206. Gordon AW, Pegues JC, Johnson GR, Kannan B, Auersperg N, Stromberg K. mRNA phenotyping of the major ligands and receptors of the EGF supergene family in human ovarian epithelial cells. Cancer Lett. 1995; 89(1):63-71. [PubMed: 7882303]

207. Mullen P, Cameron DA, Hasmann M, Smyth JF, Langdon SP. Sensitivity to pertuzumab (2C4) in ovarian cancer models: cross-talk with estrogen receptor signaling. Mol Cancer Ther. 2007; 6(1): 93-100. [PubMed: 17237269]

208. Ottensmeier C, Swanson L, Strobel T, Druker B, Niloff J, Cannistra SA. Absence of constitutive EGF receptor activation in ovarian cancer cell lines. Br J Cancer. 1996; 74(3):446-452. [PubMed: 8695362]

209. Qiu L, Di W, Jiang Q, et al. Targeted inhibition of transient activation of the EGFR-mediated cell survival pathway enhances paclitaxel-induced ovarian cancer cell death. Int J Oncol. 2005; 27(5): 1441-1448. [PubMed: 16211241]

210. Abuharbeid S, Apel J, Sander M, et al. Cytotoxicity of the novel anti-cancer drug rViscumin depends on HER-2 levels in SKOV-3 cells. Biochem Biophys Res Commun. 2004; 321(2):403412. [PubMed: 15358191]

211. Anderson NG, Ahmad T, Chan K, Dobson R, Bundred NJ. ZD1839 (Iressa), a novel epidermal growth factor receptor (EGFR) tyrosine kinase inhibitor, potently inhibits the growth of EGFRpositive cancer cell lines with or without erbB2 overexpression. Int J Cancer. 2001; 94(6):774782. [PubMed: 11745477]

212. Dean GS, Pusztai L, Xu FJ, et al. Cell surface density of p185(c-erbB-2) determines susceptibility to anti-p185(c-erbB-2)-ricin A chain (RTA) immunotoxin therapy alone and in combination with anti-p170(EGFR)-RTA in ovarian cancer cells. Clin Cancer Res. 1998; 4(10):2545-2550. [PubMed: 9796989]

213. Grunt TW. Tyrphostins and retinoids cooperate during inhibition of in vitro growth of ovarian cancer cells. Cancer Lett. 2003; 189(2):147-156. [PubMed: 12490307]

214. Lu C, Kamat AA, Lin YG, et al. Dual targeting of endothelial cells and pericytes in antivascular therapy for ovarian carcinoma. Clin Cancer Res. 2007; 13(14):4209-4217. [PubMed: 17634550]

215. Marth C, Cronauer MV, Doppler W, Ofner D, Ullrich A, Daxenbichler G. Effects of interferons on the expression of the proto-oncogene HER-2 in human ovarian carcinoma cells. Int J Cancer. 1992; 50(1):64-68. [PubMed: 1370227]

216. Takai N, Jain A, Kawamata N, et al. 2C4, a monoclonal antibody against HER2, disrupts the HER kinase signaling pathway and inhibits ovarian carcinoma cell growth. Cancer. 2005; 104(12): 2701-2708. [PubMed: 16265675]

217. Ciardiello F, Caputo R, Bianco R, et al. Inhibition of growth factor production and angiogenesis in human cancer cells by ZD1839 (Iressa), a selective epidermal growth factor receptor tyrosine kinase inhibitor. Clin Cancer Res. 2001; 7(5):1459-1465. [PubMed: 11350918]

218. Hsieh CY, Chen CA, Chou CH, et al. Overexpression of Her-2/NEU in epithelial ovarian carcinoma induces vascular endothelial growth factor $\mathrm{C}$ by activating NF-kappa B: implications for malignant ascites formation and tumor lymphangiogenesis. J Biomed Sci. 2004; 11(2):249_ 259. [PubMed: 14966375]

219. Ye D, Mendelsohn J, Fan Z. Augmentation of a humanized anti-HER2 mAb 4D5 induced growth inhibition by a human-mouse chimeric anti-EGF receptor mAb C225. Oncogene. 1999; 18(3): 731-738. [PubMed: 9989823]

220. Bull Phelps SL, Schorge JO, Peyton MJ, et al. Implications of EGFR inhibition in ovarian cancer cell proliferation. Gynecol Oncol. 2008; 109(3):411-417. [PubMed: 18423824]

221. Itamochi H, Kigawa J, Kanamori Y, et al. Adenovirus type 5 E1A gene therapy for ovarian clear cell carcinoma: a potential treatment strategy. Mol Cancer Ther. 2007; 6(1):227-235. [PubMed: 17218636]

222. Servidei T, Riccardi A, Mozzetti S, Ferlini C, Riccardi R. Chemoresistant tumor cell lines display altered epidermal growth factor receptor and HER3 signaling and enhanced sensitivity to gefitinib. Int J Cancer. 2008; 123(12):2939-2949. [PubMed: 18803287]

223. Taetle R, Honeysett JM, Houston LL. Effects of anti-epidermal growth factor (EGF) receptor antibodies and an anti-EGF receptor recombinant-ricin A chain immunoconjugate on growth of human cells. J Natl Cancer Inst. 1988; 80(13):1053-1059. [PubMed: 3261802] 
224. Arencibia JM, Bajo AM, Schally AV, Krupa M, Chatzistamou I, Nagy A. Effective treatment of experimental ES-2 human ovarian cancers with a cytotoxic analog of luteinizing hormonereleasing hormone AN-207. Anticancer Drugs. 2002; 13(9):949-956. [PubMed: 12394258]

225. Boente MP, Berchuck A, Whitaker RS, et al. Suppression of diacylglycerol levels by antibodies reactive with the c-erbB-2 (HER-2/ neu) gene product p185c-erbB-2 in breast and ovarian cancer cell lines. Gynecol Oncol. 1998; 70(1):49-55. [PubMed: 9698473]

226. Bourguignon LY, Zhu H, Zhou B, Diedrich F, Singleton PA, Hung MC. Hyaluronan promotes CD44v3-Vav2 interaction with Grb2-p185(HER2) and induces Rac1 and Ras signaling during ovarian tumor cell migration and growth. J Biol Chem. 2001; 276(52):48679-48692. [PubMed: 11606575]

227. Caliaro MJ, Vitaux P, Lafon C, et al. Multifactorial mechanism for the potentiation of cisplatin (CDDP) cytotoxicity by all-trans retinoic acid (ATRA) in human ovarian carcinoma cell lines. $\mathrm{Br}$ J Cancer. 1997; 75(3):333-340. [PubMed: 9020476]

228. Camoratto AM, Jani JP, Angeles TS, et al. CEP-751 inhibits TRK receptor tyrosine kinase activity in vitro exhibits anti-tumor activity. Int J Cancer. 1997; 72(4):673-679. [PubMed: 9259409]

229. Casalini P, Botta L, Menard S. Role of p53 in HER2-induced proliferation or apoptosis. J Biol Chem. 2001; 276(15):12449-12453. [PubMed: 11278558]

230. Cassinelli G, Lanzi C, Pensa T, et al. Clavilactones, a novel class of tyrosine kinase inhibitors of fungal origin. Biochem Pharmacol. 2000; 59(12):1539-1547. [PubMed: 10799650]

231. Chan SD, Antoniucci DM, Fok KS, et al. Heregulin activation of extracellular acidification in mammary carcinoma cells is associated with expression of HER2 and HER3. J Biol Chem. 1995; 270(38):22608-22613. [PubMed: 7673253]

232. Chatzistamou I, Schally AV, Szepeshazi K, Groot K, Hebert F, Arencibia JM. Inhibition of growth of ES-2 human ovarian cancers by bombesin antagonist RC-3095, and luteinizing hormone-releasing hormone antagonist Cetrorelix. Cancer Lett. 2001; 171(1):37-45. [PubMed: 11485826]

233. Chekhun VF, Lukyanova NY, Urchenko OV, Kulik GI. The role of expression of the components of proteome in the formation of molecular profile of human ovarian carcinoma A2780 cells sensitive and resistant to cisplatin. Exp Oncol. 2005; 27(3):191-195. [PubMed: 16244579]

234. Choi JH, Choi KC, Auersperg N, Leung PC. Gonadotropins upregulate the epidermal growth factor receptor through activation of mitogen-activated protein kinases and phosphatidylinositol-3-kinase in human ovarian surface epithelial cells. Endocr Relat Cancer. 2005; 12(2): 407-421. [PubMed: 15947112]

235. Doherty JK, Bond CT, Hua W, Adelman JP, Clinton GM. An alternative HER-2/neu transcript of $8 \mathrm{~kb}$ has an extended 3'UTR and displays increased stability in SKOV-3 ovarian carcinoma cells. Gynecol Oncol. 1999; 74(3):408-415. [PubMed: 10479501]

236. Douglas TH, Morgan TO, McLeod DG, et al. Comparison of serum prostate specific membrane antigen, prostate specific antigen, and free prostate specific antigen levels in radical prostatectomy patients. Cancer. 1997; 80(1):107-114. [PubMed: 9210715]

237. Edwards J, Bartlett JM. Induction of apoptosis and inhibition of cellular proliferation as a dual approach to treatment of ovarian cancer. Int J Oncol. 1999; 15(3):583-588. [PubMed: 10427144]

238. Ellerbroek SM, Hudson LG, Stack MS. Proteinase requirements of epidermal growth factorinduced ovarian cancer cell invasion. Int J Cancer. 1998; 78(3):331-337. [PubMed: 9766568]

239. Ferrandina G, Scambia G, Benedetti Panici P, et al. Effects of dexamethasone on the growth and epidermal growth factor receptor expression of the OVCA 433 ovarian cancer cells. Mol Cell Endocrinol. 1992; 83(2-3):183-193. [PubMed: 1372274]

240. Gercel-Taylor C, Taylor DD. Effect of patient-derived lipids on in vitro expression of oncogenes by ovarian tumor cells. Gynecol Obstet Invest. 1996; 42(1):42-48. [PubMed: 8840178]

241. Grunt TW, Oeller H, Somay C, et al. Modulation of the immunophenotype of ovarian cancer cells by N,N-dimethylformamide and transforming growth factor-beta 1. J Cell Physiol. 1993; 156(2): 358-366. [PubMed: 8344991]

Future Med Chem. Author manuscript; available in PMC 2015 October 26. 
242. Grunt TW, Puckmair K, Tomek K, Kainz B, Gaiger A. An EGF receptor inhibitor induces RARbeta expression in breast and ovarian cancer cells. Biochem Biophys Res Commun. 2005; 329(4):1253-1259. [PubMed: 15766561]

243. Grunt TW, Somay C, Oeller H, Dittrich E, Dittrich C. Comparative analysis of the effects of dimethyl sulfoxide and retinoic acid on the antigenic pattern of human ovarian adenocarcinoma cells. J Cell Sci. 1992; 103(Pt 2):501-509. [PubMed: 1478951]

244. Guo XN, Zhong L, Tan JZ, et al. In vitro pharmacological characterization of TKI-28, a broadspectrum tyrosine kinase inhibitor with anti-tumor and anti-angiogenic effects. Cancer Biol Ther. 2005; 4(10):1125-1132. [PubMed: 16096368]

245. Guo XN, Zhong L, Zhang XH, et al. Evaluation of active recombinant catalytic domain of human ErbB-2 tyrosine kinase, and suppression of activity by a naturally derived inhibitor, ZH-4B. Biochim Biophys Acta. 2004; 1673(3):186-193. [PubMed: 15279890]

246. Hartmann F, Horak EM, Cho C, et al. Effects of the tyrosine-kinase inhibitor geldanamycin on ligand-induced Her-2/neu activation, receptor expression and proliferation of Her-2-positive malignant cell lines. Int J Cancer. 1997; 70(2):221-229. [PubMed: 9009164]

247. Hsieh SS, Malerczyk C, Aigner A, Czubayko F. ERbB-2 expression is rate-limiting for epidermal growth factor-mediated stimulation of ovarian cancer cell proliferation. Int J Cancer. 2000; 86(5): 644-651. [PubMed: 10797285]

248. Hua W, Christianson T, Rougeot C, Rochefort H, Clinton GM. SKOV3 ovarian carcinoma cells have functional estrogen receptor but are growth-resistant to estrogen and antiestrogens. J Steroid Biochem Mol Biol. 1995; 55(3-4):279-289. [PubMed: 8541224]

249. Jeschke M, Wels W, Dengler W, Imber R, Stocklin E, Groner B. Targeted inhibition of tumorcell growth by recombinant heregulin-toxin fusion proteins. Int J Cancer. 1995; 60(5):730-739. [PubMed: 7860149]

250. Johnson AC, Murphy BA, Matelis CM, et al. Activator protein-1 mediates induced but not basal epidermal growth factor receptor gene expression. Mol Med. 2000; 6(1):17-27. [PubMed: 10803405]

251. Jones J, Lagasse LD, Karlan BY. Steroid hormonal independence of HER-2/neu mRNA expression in four human ovarian carcinoma cell lines. Gynecol Oncol. 1994; 55(3 Pt 1):421426. [PubMed: 7835782]

252. Juhl H, Downing SG, Wellstein A, Czubayko F. HER-2/neu is rate-limiting for ovarian cancer growth. Conditional depletion of HER-2/neu by ribozyme targeting. J Biol Chem. 1997; 272(47): 29482-29486. [PubMed: 9368008]

253. Kao MC, Liu GY, Chuang TC, Lin YS, Wuu JA, Law SL. The N-terminal 178-amino-acid domain only of the SV40 large T antigen acts as a transforming suppressor of the HER-2/neu oncogene. Oncogene. 1998; 16(4):547-554. [PubMed: 9484845]

254. Karlan BY, Jones J, Slamon DJ, Lagasse LD. Glucocorticoids stabilize HER-2/neu messenger RNA in human epithelial ovarian carcinoma cells. Gynecol Oncol. 1994; 53(1):70-77. [PubMed: 7909787]

255. King BL, Carter D, Foellmer HG, Kacinski BM. Neu proto-oncogene amplification and expression in ovarian adenocarcinoma cell lines. Am J Pathol. 1992; 140(1):23-31. [PubMed: 1346236]

256. Klutchko SR, Hamby JM, Boschelli DH, et al. 2-Substituted aminopyrido[2,3-d]pyrimidin-7(8H)ones. structure-activity relationships against selected tyrosine kinases and in vitro and in vivo anticancer activity. J Med Chem. 1998; 41(17):3276-3292. [PubMed: 9703473]

257. Lee H, Maihle NJ. Isolation and characterization of four alternate c-erbB3 transcripts expressed in ovarian carcinoma-derived cell lines and normal human tissues. Oncogene. 1998; 16(25):32433252. [PubMed: 9681822]

258. Lui VW, He Y, Huang L. Specific down-regulation of HER-2/neu mediated by a chimeric U6 hammerhead ribozyme results in growth inhibition of human ovarian carcinoma. Mol Ther. 2001; 3(2):169-177. [PubMed: 11237673]

259. Marth C, Lang T, Cronauer MV, et al. Epidermal growth factor reduces HER-2 protein level in human ovarian carcinoma cells. Int J Cancer. 1992; 52(2):311-316. [PubMed: 1355758] 
260. Provencher DM, Lounis H, Champoux L, et al. Characterization of four novel epithelial ovarian cancer cell lines. In Vitro Cell Dev Biol Anim. 2000; 36(6):357-361. [PubMed: 10949993]

261. Rodriguez GC, Berchuck A, Whitaker RS, Schlossman D, Clarke-Pearson DL, Bast RC Jr. Epidermal growth factor receptor expression in normal ovarian epithelium and ovarian cancer. II. Relationship between receptor expression and response to epidermal growth factor. Am J Obstet Gynecol. 1991; 164(3):745-750. [PubMed: 2003535]

262. Rodriguez GC, Boente MP, Berchuck A, et al. The effect of antibodies and immunotoxins reactive with HER-2/neu on growth of ovarian and breast cancer cell lines. Am J Obstet Gynecol. 1993; 168(1 Pt 1):228-232. [PubMed: 8420332]

263. Scoles DR, Pavelka J, Cass I, et al. Characterization of CSOC 882, a novel immortalized ovarian cancer cell line expressing EGFR, HER2, and activated AKT. Gynecol Oncol. 2007; 104(1):120128. [PubMed: 16956650]

264. Simpson BJ, Bartlett JM, Macleod KG, et al. Inhibition of transforming growth factor alpha (TGF-alpha)-mediated growth effects in ovarian cancer cell lines by a tyrosine kinase inhibitor ZM 252868. Br J Cancer. 1999; 79(7-8):1098-1103. [PubMed: 10098742]

265. Stromberg K, Collins TJT, Gordon AW, Jackson CL, Johnson GR. Transforming growth factoralpha acts as an autocrine growth factor in ovarian carcinoma cell lines. Cancer Res. 1992; 52(2): 341-347. [PubMed: 1309440]

266. Tang P, Hung MC, Klostergaard J. TNF cytotoxicity: effects of HER-2/neu expression and inhibitors of ADP-ribosylation. Lymphokine Cytokine Res. 1994; 13(2):117-123. [PubMed: 7914750]

267. Vacca F, Bagnato A, Catt KJ, Tecce R. Transactivation of the epidermal growth factor receptor in endothelin-1-induced mitogenic signaling in human ovarian carcinoma cells. Cancer Res. 2000; 60(18):5310-5317. [PubMed: 11016663]

268. Wiechen K, Karaaslan S, Dietel M. Involvement of the c-erbB-2 oncogene product in the EGFinduced cell motility of SK-OV-3 ovarian cancer cells. Int J Cancer. 1999; 83(3):409-414. [PubMed: 10495435]

269. Witters L, Kumar R, Mandal M, Bennett CF, Miraglia L, Lipton A. Antisense oligonucleotides to the epidermal growth factor receptor. Breast Cancer Res Treat. 1999; 53(1):41-50. [PubMed: 10206071]

270. Xu F, Yu Y, Le XF, Boyer C, Mills GB, Bast RC Jr. The outcome of heregulin-induced activation of ovarian cancer cells depends on the relative levels of HER-2 and HER-3 expression. Clin Cancer Res. 1999; 5(11):3653-3660. [PubMed: 10589783]

271. Yu D, Wolf JK, Scanlon M, Price JE, Hung MC. Enhanced c-erbB-2/neu expression in human ovarian cancer cells correlates with more severe malignancy that can be suppressed by E1A. Cancer Res. 1993; 53(4):891-898. [PubMed: 8094034]

272. Sedlak J, McGown A, Hrubisko M, Hunakova L, Chorvath B. Drug-resistance associated alterations of cell surface antigen expression in a human anthracycline-resistant ovarian carcinoma cell line. Neoplasma. 1994; 41(5):259-262. [PubMed: 7854495]

273. Arencibia JM, Schally AV, Krupa M, et al. Targeting of doxorubicin to ES-2 human ovarian cancers in nude mice by linking to an analog of luteinizing hormone-releasing hormone improves its effectiveness. Int J Oncol. 2001; 19(3):571-577. [PubMed: 11494038]

274. Kammerer U, Thanner F, Kapp M, Dietl J, Sutterlin M. Expression of tumor markers on breast and ovarian cancer cell lines. Anticancer Res. 2003; 23(2A):1051-1055. [PubMed: 12820346]

275. Kutteh WH, Miller DS, Mathis JM. Immunologic characterization of tumor markers in human ovarian cancer cell lines. J Soc Gynecol Investig. 1996; 3(4):216-222.

276. Zhou L, Leung BS. Growth regulation of ovarian cancer cells by epidermal growth factor and transforming growth factors alpha and beta 1. Biochim Biophys Acta. 1992; 1180(2):130-136. [PubMed: 1463764]

277. Christen RD, Hom DK, Porter DC, et al. Epidermal growth factor regulates the in vitro sensitivity of human ovarian carcinoma cells to cisplatin. J Clin Invest. 1990; 86(5):1632-1640. [PubMed: 2243136]

Future Med Chem. Author manuscript; available in PMC 2015 October 26. 
278. Sain N, Krishnan B, Ormerod MG, et al. Potentiation of paclitaxel activity by the HSP90 inhibitor 17-allylamino-17-demethoxygeldanamycin in human ovarian carcinoma cell lines with high levels of activated AKT. Mol Cancer Ther. 2006; 5(5):1197-1208. [PubMed: 16731752]

279. Bartholomeusz C, Oishi T, Saso H, et al. MEK 1/2 Inhibitor selumetinib (AZD6244) inhibits growth of ovarian clear cell carcinoma in a PEA-15-dependent manner in a mouse xenograft model. Mol Cancer Ther. 2011; 11(2):360-369. [PubMed: 22144664]

280. Brunner-Kubath C, Shabbir W, Saferding V, et al. The PI3 kinase/mTOR blocker NVP-BEZ235 overrides resistance against irreversible ErbB inhibitors in breast cancer cells. Breast Cancer Res Treat. 2011; 129(2):387-400. [PubMed: 21046231]

281. Fujimura M, Katsumata N, Tsuda H, et al. HER2 is frequently over-expressed in ovarian clear cell adenocarcinoma: possible novel treatment modality using recombinant monoclonal antibody against HER2, trastuzumab. Jpn J Cancer Res. 2002; 93(11):1250-1257. [PubMed: 12460467]

282. Haluska P, Carboni JM, TenEyck C, et al. HER receptor signaling confers resistance to the insulin-like growth factor-I receptor inhibitor, BMS-536924. Mol Cancer Ther. 2008; 7(9):25892598. [PubMed: 18765823]

283. Luistro LL 3rd, Tovar C, Bishayee S, Rameshwar P, Ponzio NM, Ritland SR. Development and characterization of a pre-clinical model of ovarian carcinoma to investigate mechanisms of resistance to the anti-HER2/neu antibody herceptin. Proc Am Assoc Cancer Res. 2004; 45:1205.

284. Pack SD, Alper OM, Stromberg K, et al. Simultaneous suppression of epidermal growth factor receptor and c-erbB-2 reverses aneuploidy and malignant phenotype of a human ovarian carcinoma cell line. Cancer Res. 2004; 64(3):789-794. [PubMed: 14871800]

285. Yanagibashi T, Gorai I, Nakazawa T, et al. Complexity of expression of the intermediate flaments of six new human ovarian carcinoma cell lines: new expression of cytokeratin 20 . Br J Cancer. 1997; 76(7):829-835. [PubMed: 9328139] 


\section{Executive summary}

\section{Background}

- Most women diagnosed with epithelial ovarian cancer (EOC) present with late-stage disease.

- Advanced EOC is highly sensitive to traditional chemotherapy, but typically recurs as an aggressive, chemotherapy-resistant disease.

- Epithelial ovarian cancers frequently express HER tyrosine kinases that are drugable with novel HER-targeted therapeutics.

\section{Overview of epithelial ovarian cancer treatment}

- Contemporary EOC patient management consists of debulking surgery and platinum-plus-taxol chemotherapy.

- Most EOC patients respond to first-line chemotherapy.

- Successive cycles of disease relapse may necessitate second- or third-line chemotherapy.

\section{HER family \& ovarian cancer}

- The HER family of receptor tyrosine kinases plays a crucial role in ovarian development and also in normal ovarian tissue homeostasis.

- Aberrant HER expression and activation are common in ovarian cancer.

- Lack of standardized measurement of HER family members and their transcripts confound studies associating HER expression and disease characteristics.

\section{HER-targeted therapeutics}

- Numerous HER-directed therapeutics, including reversible tyrosine kinase inhibitors, irreversible tyrosine kinase inhibitors and therapeutic antibodies, are in various stages of development for clinical use.

\section{Effect of HER inhibitors on epithelial ovarian cancer-derived cells in vitro}

- HER-targeted therapeutics inhibit numerous malignant processes in vitro, including cell proliferation, survival, anchorage-independence and activation of mitogenic and survival signaling pathways.

- Lack of congruence between apparent HER expression levels and response to novel therapeutics may depend on: the mechanism of drug action; compensatory activity of other signal pathways; and reliability of 'HER expression' testing methods, among others.

\section{HER inhibitors for the treatment of epithelial ovarian cancer patients}

Clinical trials of HER-targeted therapeutics for the treatment of ovarian cancer over the past decade have yielded only modest results to date. 
Lack of randomization, especially in frontline trials in combination with platinum and taxane chemotherapy, make it difficult to assess the clinical utility of HER-targeted therapeutics for the treatment of ovarian cancer.

\section{Future perspective}

- A meta-analysis suggests no association between HER expression in ovarian carcinoma-derived cells and responsiveness to HER-directed therapeutics.

- Some ovarian cancer patients respond to HER-targeted therapeutics; these observations suggest that future studies targeting this receptor family remain a viable option for more effective treatment of a significant subpopulation of ovarian cancer patients.

- Improved methods for identification of this subpopulation will be required for optimal testing of these new candidate drugs.

- Information regarding the complexities of HER receptor signaling, as well as the limitations of current methods for assessing HER expression, has not been optimally integrated into clinical trial design strategies for the testing of HER-targeted drugs.

Use of new in vitro and in vivo (animal) models of epithelial ovarian cancer may improve methods of selection for patients potentially responsive to HER-targeted therapeutics. 


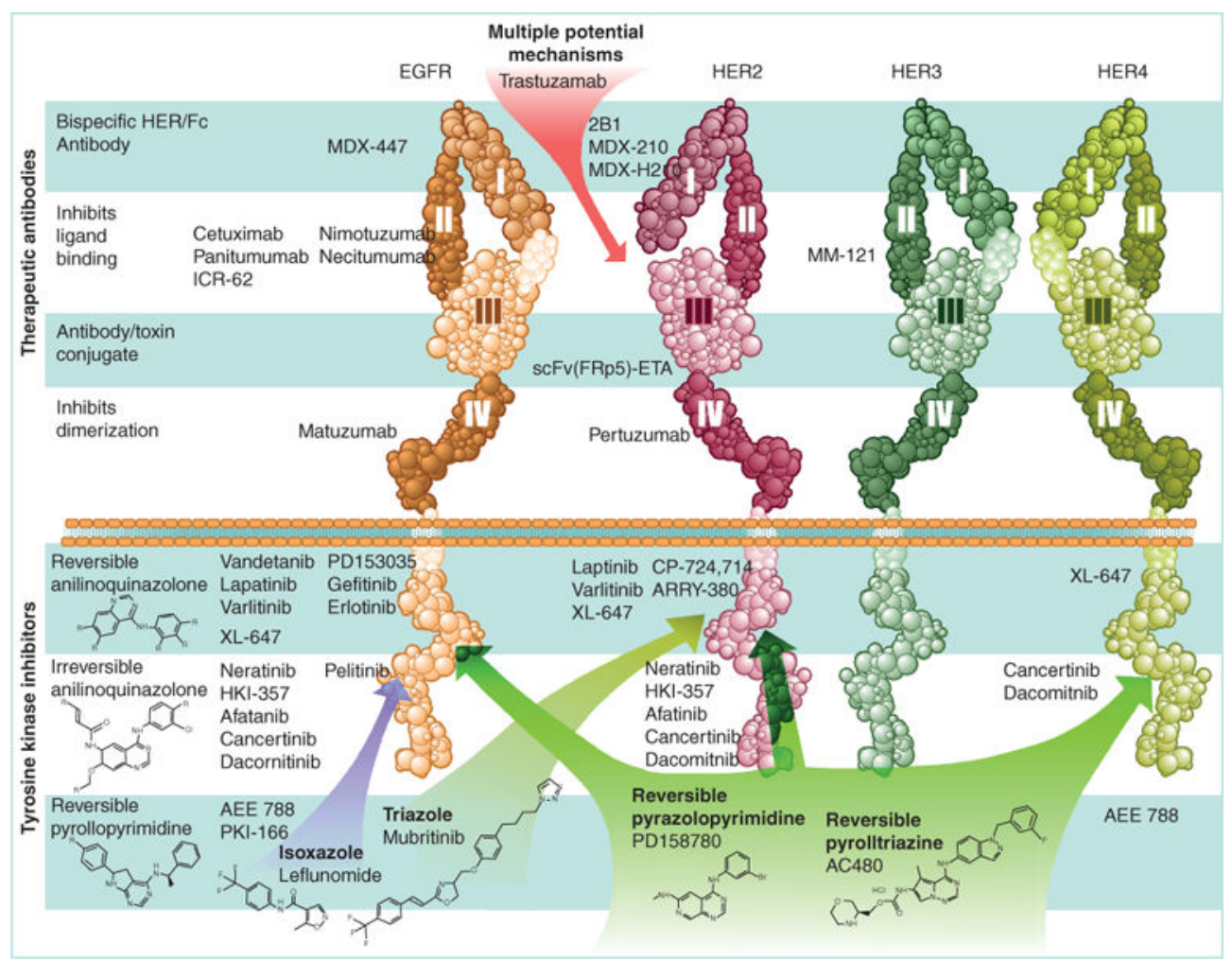

Figure 1. Design of HER-directed therapeutics

HER family members consist of an extracellular domain (divided into subdomains I-IV, with subdomains I and III regulating ligand binding), a transmembrane domain and an intracellular domain containing an ATP-binding tyrosine kinase domain. Ligand binding induces HER dimerization and transphosphorylation of intracellular domains, initiating signal cascades. Therapeutic antibodies, directed against HER extracellular domains, inhibit ligand binding and/or receptor dimerization, deliver toxic conjugates, and/or recruit immune cells. Small-molecule HER inhibitors reversibly or irreversibly inhibit HER tyrosine kinase activity. Each therapeutic antibody or small-molecule inhibitor shown has been tested in vitro, in vivo or in clinical studies of epithelial ovarian cancer. Cartoon structures of HER family members are not drawn to scale and not based on reported crystal structures. 


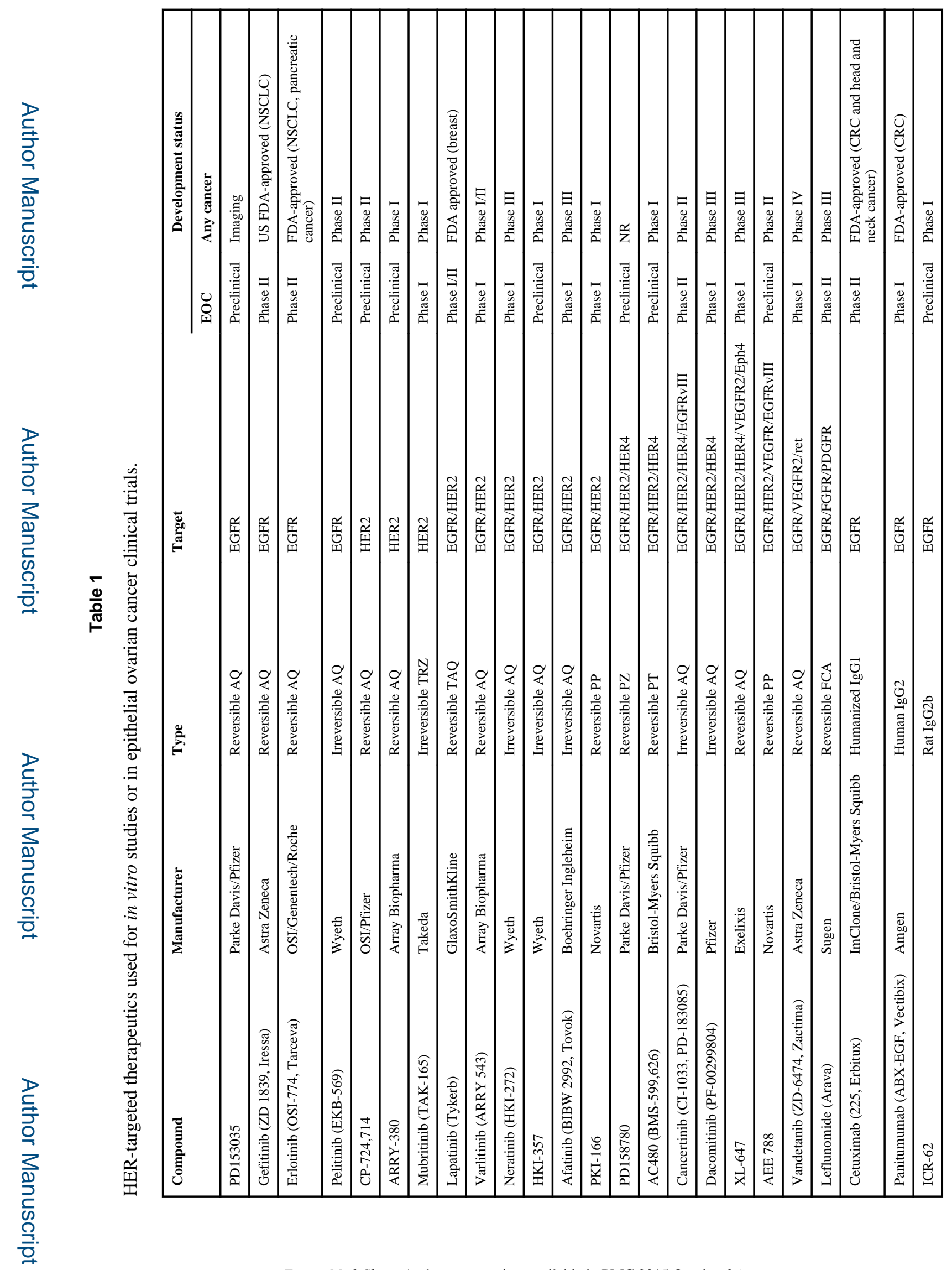

Future Med Chem. Author manuscript; available in PMC 2015 October 26. 


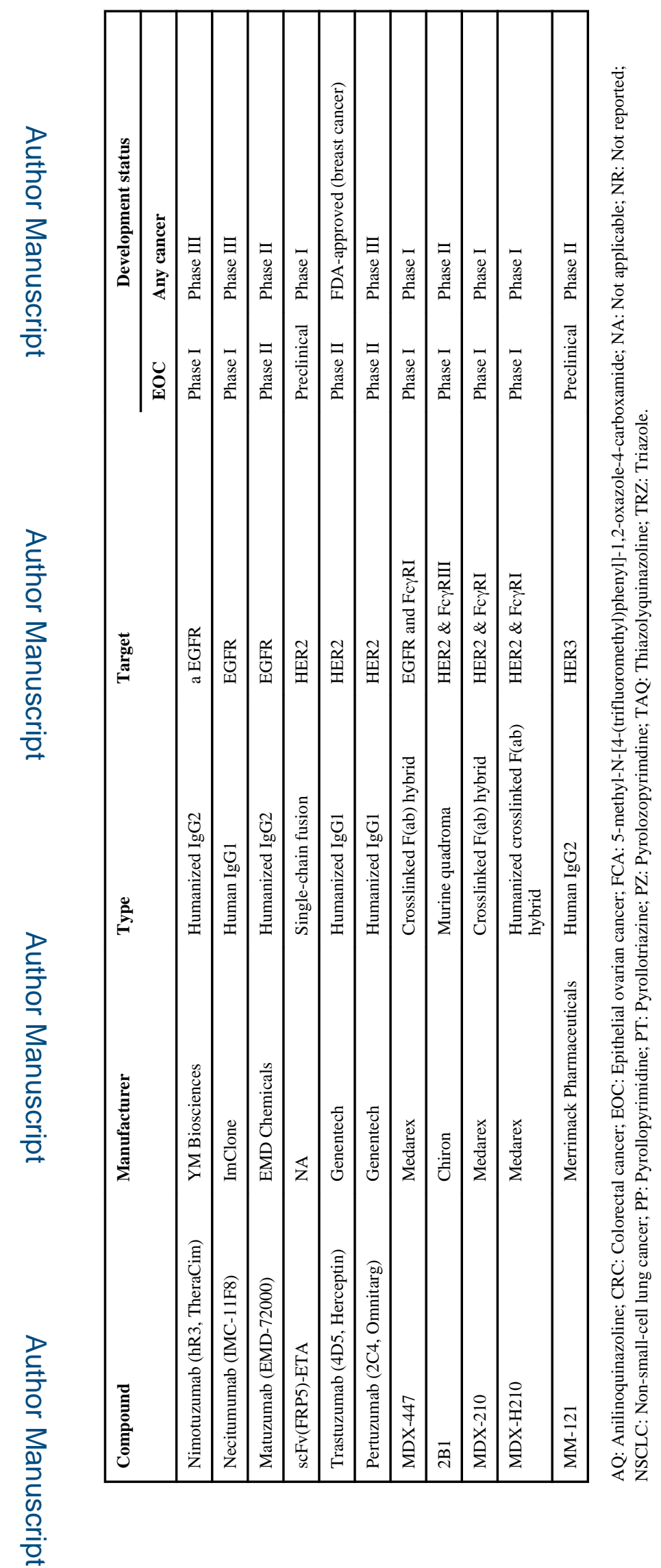

Future Med Chem. Author manuscript; available in PMC 2015 October 26. 


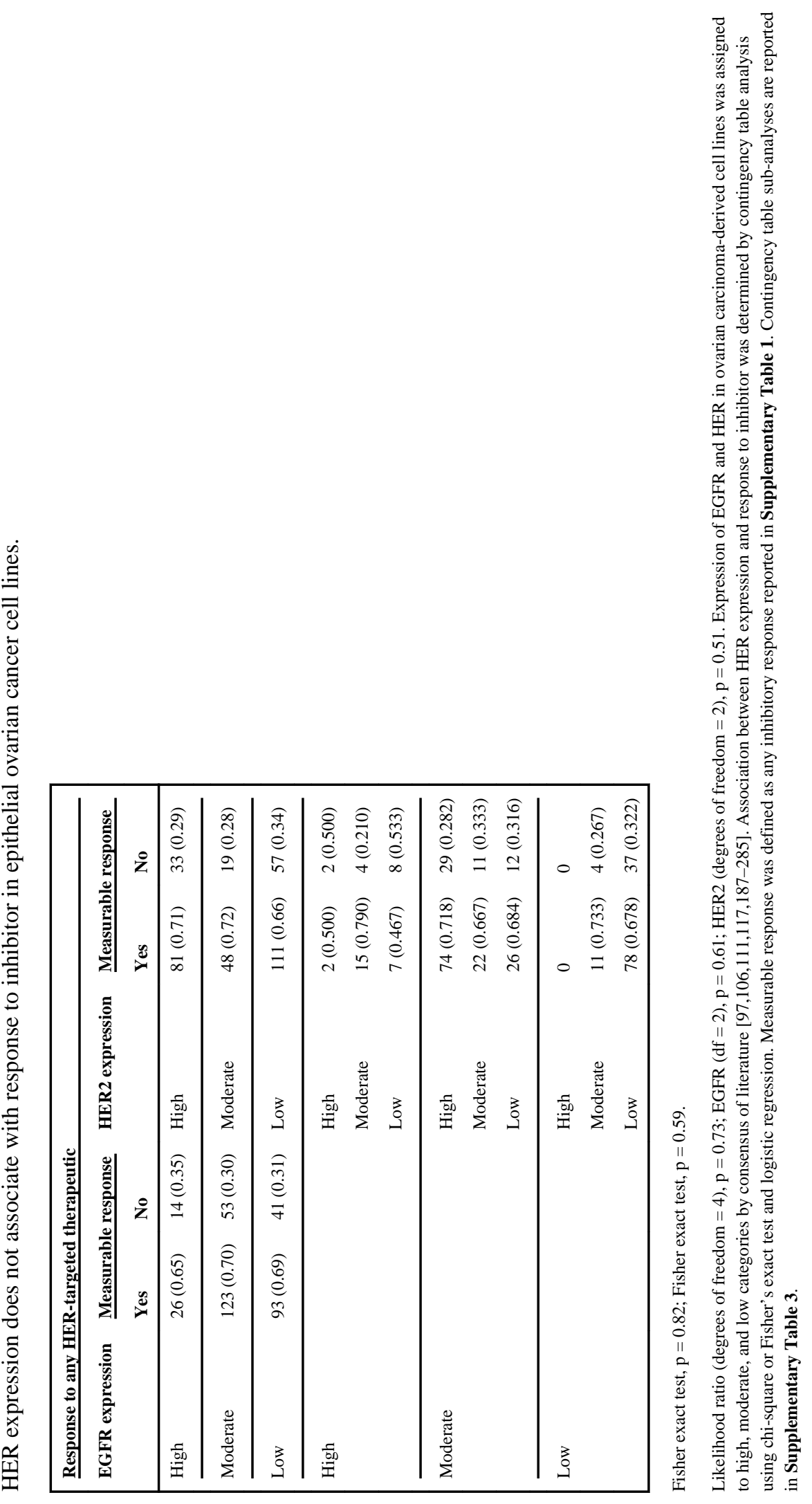

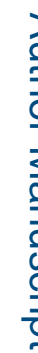

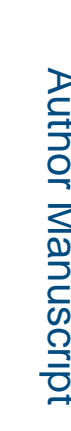

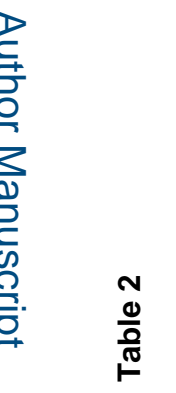

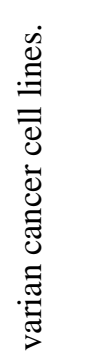

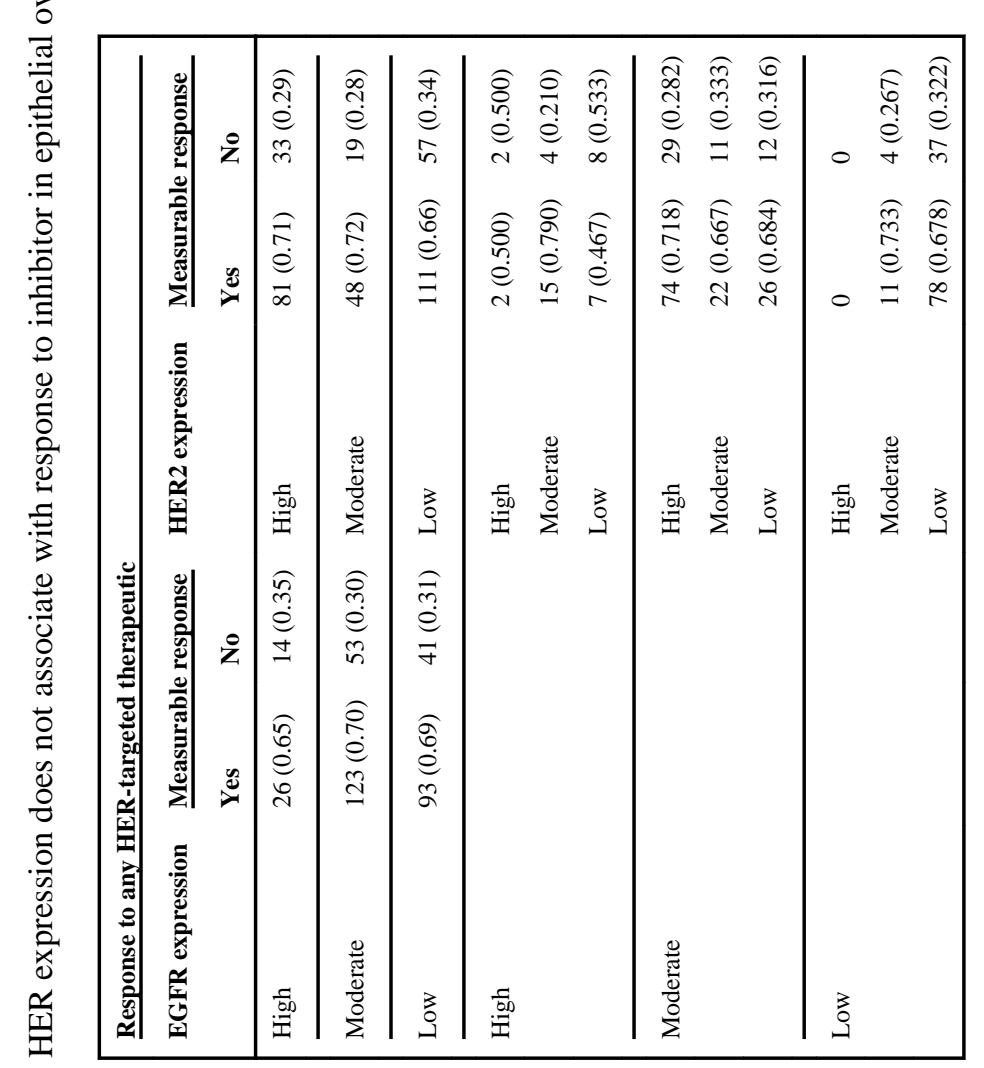

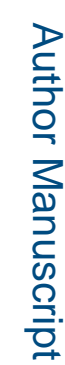

Future Med Chem. Author manuscript; available in PMC 2015 October 26. 